\title{
Obesity and the gut microbiota: does up-regulating colonic fermentation protect against obesity and metabolic disease?
}

\author{
Lorenza Conterno $\cdot$ Francesca Fava . \\ Roberto Viola $\cdot$ Kieran M. Tuohy
}

Received: 16 March 2011/Accepted: 20 April 2011/Published online: 11 May 2011

(C) Springer-Verlag 2011

\begin{abstract}
Obesity is now considered a major public health concern globally as it predisposes to a number of chronic human diseases. Most developed countries have experienced a dramatic and significant rise in obesity since the 1980s, with obesity apparently accompanying, hand in hand, the adoption of "Western"-style diets and lowenergy expenditure lifestyles around the world. Recent studies report an aberrant gut microbiota in obese subjects and that gut microbial metabolic activities, especially carbohydrate fermentation and bile acid metabolism, can impact on a number of mammalian physiological functions linked to obesity. The aim of this review is to present the evidence for a characteristic "obese-type" gut microbiota and to discuss studies linking microbial metabolic activities with mammalian regulation of lipid and glucose metabolism, thermogenesis, satiety, and chronic systemic inflammation. We focus in particular on short-chain fatty acids (SCFA) produced upon fiber fermentation in the colon. Although SCFA are reported to be elevated in the feces of obese individuals, they are also, in contradiction, identified as key metabolic regulators of the physiological checks and controls mammals rely upon to regulate energy metabolism. Most studies suggest that the gut microbiota differs in composition between lean and obese individuals and that diet, especially the high-fat low-fiber Western-style diet, dramatically impacts on the gut microbiota. There is currently no consensus as to whether the gut microbiota plays
\end{abstract}

L. Conterno $(\varangle) \cdot$ F. Fava $~ K$ K. M. Tuohy

Nutrition and Nutrigenomics Group, Research and Innovation Centre, FEM-IASMA, 38010 S. Michele a.A, Trento, Italy

e-mail: lorenza.conterno@iasma.it

R. Viola

Research and Innovation Centre, FEM-IASMA,

38010 S. Michele a.A, Trento, Italy a causative role in obesity or is modulated in response to the obese state itself or the diet in obesity. Further studies, especially on the regulatory role of SCFA in human energy homeostasis, are needed to clarify the physiological consequences of an "obese-style" microbiota and any putative dietary modulation of associated disease risk.

Keywords Obesity · Microbiota - SCFA · Fiber . Prebiotics · Probiotics

\section{Introduction}

Obesity is now considered among the top public health issues worldwide. In many countries, obesity rates reported before 1980 were below $10 \%$, whereas nearly half of the Organization for Economic Co-operation and Development (OECD) countries now report $50 \%$ or more of the population as being overweight, with the percentage obese reaching 20 to $30 \%$ (OECD 2010). Obesity has a dramatic impact on the body, with major changes in energy metabolism and regulatory mechanisms leading to type 2 diabetes, cardiovascular disease (CVD), hormone-linked cancers, and gastrointestinal diseases including inflammatory bowel disease and colon cancer. Characteristic physiological perturbation in terms of hormonal imbalances (e.g., elevated leptin and insulin) and chronically elevated glucose and blood lipids (TAG, cholesterol) occur in congruence with oxidative stress and chronic systemic inflammation, which itself leads to cellular damage in diverse body tissues including the liver, pancreas, vascular system, and the intestinal mucosa. Obesity therefore is a key risk factor for numerous chronic diseases including CVD, the metabolic syndrome, type 2 diabetes, and certain cancers (Pi-Sunyer 2009). 
Data collected about this new epidemic of obesity are revealing a complicated network of contributory factors including genetics, age, diet, and nutritional environment. However, the rapid increase in obesity over such a short time frame makes a novel genetic cause per se unlikely and strongly favors modified environmental factors over the past 30 years. Such environmental factors include dietary habit, exercise or energy expenditure, and lifestyle. Indeed, there appears to be a strong correlation between Westernization in terms of diet and lifestyle and obesity. Reduced energy expenditure of modern lifestyles and a Westernstyle diet prevalent in developed nations are both implicated as causative factors in obesity and are likely to work in synergy to increase obesity rates at the population level (Lieberman 2003; Keim et al. 2004). A shift from more traditional diets, rich in whole-plant foods like whole-grain cereals, fruits, and vegetables, e.g., those of traditional Chinese, Japanese, rural African, and hunter-gatherer populations or aboriginal peoples in Australia and south America, to modern Western-style diets rich in refined carbohydrates, fat, and red/processed meats and low in fiber and whole-plant foods, is strongly correlated with increased body weight, obesity, and the diseases of obesity (O’Dea 1991; Ravussin et al. 1994; Williams et al. 2001; Novotny et al. 2009; Willcox et al. 2009). The same is seen in Europe, where poor adherence to a "Mediterranean style diet" and reduced intake of fiber, fruit, and vegetables is presaging increased body weight and obesity even in countries that traditionally have lower rates of obesity such as Italy (Celi et al. 2003; di Giuseppe et al. 2008; Baldini et al. 2009; De Filippo et al. 2010). This divergence from traditional whole-plant food-based diets and concomitant increases in body weight and diabetes in particular has been reported in genetically diverse populations from different corners of the world again strongly discounting genetics as the major cause for the current wave of obesity.

A more recently appreciated characteristic of obesity is an aberrant intestinal microbiota composition in obese individuals, which appears to be linked to the obese state itself and yet susceptible to dietary modulation (for recent reviews, see Bäckhed 2010; Ley 2010; Tuohy et al. 2010). Whether this aberrant microbiota composition plays an etiological role in obesity or is a consequence of the diet in obesity remains to be determined with evidence from different laboratories, models systems, and human studies supporting either hypothesis (Ley et al. 2006; Duncan et al. 2007). However, this in itself is not surprising considering the complex interplay between the resident human intestinal microbiota and diverse mammalian physiological systems including the immune system, endocrine system, and importantly, energy homeostasis and lipid metabolism. Also the fact that diet, especially dietary fiber, is already known to modify microbial profiles and fermentative output of the gut microbiota would make a low-fiber Western-style obesogenic diet a likely candidate for impacting on gut microbiota composition and activity (Tuohy et al. 2009a, b; De Filippo et al. 2010). Further, recent metagenomic studies are suggesting that many metabolic functions within the gut microbiota are shared between diverse species, suggesting that ecological function may not be as closely linked to bacterial phylogenetics as we have assumed in the past and that although certain groups of indicator organisms may predict either a healthy microbiota (e.g., the bifidobacteria and lactobacilli) or one more likely to be associated with disease (e.g., elevated numbers of enterobacteria), when trying to correlate a phenotypic trait as globally pervasive as energy metabolism, it may not be surprising that different studies show different results in terms of microbial populations correlating with obesity (Cummings et al. 2004).

In the following text, we present a review of studies showing that the gut microbiota, both in composition and metabolic activity, appears to be different in obese compared with lean individuals and discuss the different mechanisms suggested to link aberrant intestinal microbiota profiles with obesity and the diseases of obesity (Table 1). We discuss these recent observations with respect to mechanistic nutritional studies linking colonic fermentation and microbial metabolites, in particular the short-chain fatty acids, acetate, propionate, and butyrate to the regulation of mammalian energy metabolism and body composition.

\section{Is the gut microbiota altered in obesity?}

\section{Evidence from germ-free animals}

Some of the earliest data linking the mammalian gut microbiota with obesity and particularly, energy homeostasis and fat storage come from studies conducted in germ-free animals. These are animals raised and maintained in the complete absence of contact with living microorganisms and as such do not undergo natural physiological successional development in terms of immune education, mucosal architecture, mammalian-microbiota co-metabolic pathways (e.g., bile acid turnover or xenobiotic metabolism), and as we are finding out, energy metabolism and storage, which occur in free-living vertebrates concomitantly with gut microbiota successional development. However, they do serve as a very useful tool to elucidate fundamental mechanisms underpinning microbial communication and interactions with mammalian physiology at the systems level under controlled conditions not attainable using conventional models or in human studies. Bäckhed et al. (2004) found that transplant of gut microbiota from conventional animals (animals raised under normal, microbiota 
associated conditions) into germ-free mice (C57BL/6) led to $60 \%$ increased body fat and insulin resistance within 14 days despite reduced food intake and a $40 \%$ reduction in muscle mass. Colonization with the common mammalian anaerobic commensal Bacteroides thetaiotaomicron alone also led to a $23 \%$ increase in the total body fat. This bacterial species has a very high capacity of degrading plant polysaccharides, the major constituent of dietary fiber, which are not broken down by host-encoded enzymes. The study showed that conventionalization promoted increased monosaccharide uptake from the gut, increased delivery of monosaccharides to the liver, increased transactivation of lipogenic enzymes, and increased LPL activity leading to higher uptake of fatty acids and triglyceride accumulation. These authors were the first to show that acquisition of a gut microbiota impacts on fat deposition, clearly linking microbial activities in the intestine with mammalian energy homeostasis and obesity.

Turnbaugh et al. in 2006 showed that germ-free animals colonized with the gut microbiota from obese animals showed greater body weight and fat mass than germ-free animals colonized with the microbiota derived from lean animals. The obese donor was found to be populated by a microbiota with a higher proportion of Firmicutes than the lean donor. The recipients showed a gut microbiota profile similar to their obese donor 2 weeks after colonization. However, even if the initial body mass of the recipient and the chow consumption during the 2 weeks was not statistically different, mice colonized with the obese microbiota showed a higher increase (47\%) in body fat, than their lean recipient littermates $(27 \%)$. Furthermore, using massive metagenomic sequencing, these authors showed that the gut microbiota of obese animals had a greater capacity to extract energy from the diet than the microbiota of lean animals. In fact, the obese microbiome showed an enzyme profile high in glycoside hydrolases and other enzymes responsible for transport and metabolism of the glycosides involved in the generation of fermentation end products like butyrate and acetate (Turnbaugh et al. 2006). In confirmation, cecal concentrations of short-chain fatty acids (SCFA), important energy sources absorbed by the host, accounting for about $10 \%$ of daily energy intake (Macfarlane and Gibson 1997), were higher in obese animals compared to lean (Turnbaugh et al. 2006). In a study by Samuel and Gordon (2006), gnotobiotic wild-type mice colonized with Methanobrevibacter smithii and/or $B$. thetaiotaomicron showed that co-colonization with these two bacterial species increases the feed conversion efficiency and changes the specificity of bacterial polysaccharide fermentation, driving the host to a significant increase in body fat compared with mice colonized with either one of the bacterial species alone. This study showed the important role cross-feeding plays in the energy economy of the colonic microbiota, and the consequences of microbiota modulation or changes in microbiota composition within the gut may wrought on mammalian physiology at the whole organism level.

\section{Evidence from genetic models of obesity}

Genetic predisposition to obesity in $o b / o b$ mice, due to mutation of the gene coding for leptin, the obesity hormone responsible for regulating food intake and appetite in the hypothalamus, appears to shape a peculiar gut microbiota specialized for enhanced dietary energy recovery. This microbiota was characterized by an up-regulated metabolic machinery with an enhanced capacity for energy extraction from food (Ley et al. 2005; Turnbaugh et al. 2006). Ley et al. (2005) found that these obese $o b / o b$ mice possessed a gut microbiota distinct from their lean ob/ + and $+/+$ siblings at the phylum level with a $50 \%$ reduction in the abundance of Bacteroidetes and a concomitant increase in Firmicutes. This groundbreaking study was one of the first to show that a single genetic mutation in a mammalian gene responsible for regulating food intake could impact on the composition of the mammalian gut microbiota. A later study using the Zucker fa/fa rat model of obesity, which more closely mimics common diet-induced obesity in humans where obesity is induced by resistance to leptin rather than lack of functioning leptin protein, found that in rats too, obesity was characterized by a gut microbiota profile distinct from lean phenotype littermates. Using a combination of FISH and DGGE for a broad picture of microbiota composition and relative abundance, Waldram et al. (2009) found that total bacterial numbers and numbers of the Actinobacteria, Bifidobacterium, and Atopobi$u m / C o r i o b a c t e r i u m$ were significantly lower in the obese $f a / f a$ rats and that obese animals displayed elevated numbers of the Firmicutes groups Eubacterium rectale/Blautia coccoides and lactobacilli/enterococci compared with lean counterparts. The lean $f a /-$ were characterized by a higher number of Eubacterium rectale/Blautia coccoides and lactobacilli/enterococci than the $-/-$ rats. Moreover, these authors using an NMR-based metabolomics approach showed that many of the metabolites responsible for differentiating obese from lean animals derived from combined host-gut microbiota metabolic pathways. In fact, the obese phenotype was characterized by higher amount of urine acetate but lower hippurate, creatinine, and also trimetylammine-N-oxide (TMAO). Bifidobacterial numbers in the cecum were positively correlated with hippurate and dimethylglycine in the urine. The plasma analysis discriminated the obese rats as having higher concentrations of acetoacetate, LDL, and VLDL and lower concentrations of glycine and glutamate than lean rats. Murphy et al. (2010) confirmed that the gut microbiota of $o b / o b$ 
mice and high-fat-fed wild-type animals, as discussed in more detail later, displayed a microbiota with elevated abundance of Firmicutes and reduced abundance of $\mathrm{Bac}$ teroidetes compared with lean animals. Although they also confirmed that Actinobacteria were dominant members of the gut microbiota in these animals, changes wrought by diet or obesity itself in this bacterial phylum varied greatly between individuals masking any group effects. However, they also found that the energy-harvesting potential of the microbiota appeared to be dissociated from changes within the gut microbiota at the phylum level, contrary to the Turnbaugh findings, and suggested that the energy-harvesting potential of the microbiota was more related to diet and that it also changed over time, with fecal acetate, the main SCFA fermentation end product, decreasing over the 15-week experimental period.

Evidence from diet-induced models of obesity

Recent studies have also shown that diets designed to bring on obesity and the diseases of obesity in animal models can also impact on the composition and activity of the gut microbiota. These studies are shedding new light on the complex interaction between nutrient intake (both quantity and quality), the gut microbiota, and host energy metabolism in regulating susceptibility to metabolic disease and excess body weight gain. Diet-induced obesity more closely resembles the situation in humans, where diet under the prevailing genetic constraints of a given individual drives energy storage, body fat accumulation on the one hand and thermogenesis and energy expenditure on the other. Dumas et al. (2006) studied the crosstalk between mammalian and microbiotal metabolism in dietary-induced impaired glucose homeostasis and non-alcoholic fatty liver disease (NAFLD) in the 129S6 mouse model. Using an NMR-based metabolomics approach, they observed changes in plasma and urine metabolic profiles, which differentiated animals that develop non-alcoholic fatty liver disease, insulin resistance, and later obesity on high-fat diets from lean and healthy animals. Many of the metabolites associated with disease derived from microbiotahost co-metabolism of choline, including a reduction in plasma concentrations of phosphatidylcholine and elevated urinary excretion of methylamines (dimethylamine, trimethylamine, and trimethylamine- $N$ oxide). The authors suggested that on high-fat diets, this mouse model, 129S6, developed NAFLD and insulin resistance due to conversion of choline into methylamines by their intestinal microbiota, leading to choline deficiency, mimicking the diseaseinducing effects of low-choline diets.

Cani et al. (2007a) found that mice on a high-fat $(10 \%$ w/w), low-fiber diet developed obesity with a significant concomitant "die-off" in saccharolytic bacteria within the gut microbiota. Moreover, diet-induced aberrant gut microbiota could be related to increased intestinal permeability and uptake of the inflammatory bacterial cell wall fragment lipopolysaccharide (LPS), also called endotoxin, which induced a state of chronic systemic inflammation typified by elevated TNF-alpha, IL-1, IL-6, and PAI-1 in the blood, and fat deposition in the liver, which contributed to the development of insulin resistance and subsequent obesity and type 2 diabetes. They later found that this situation could be reversed using the prebiotic fiber oligofructose, via upregulation of the gut hormone glucagon-like peptide2 (GLP-2), an important regulator of intestinal permeability, and improved intestinal function, and which in rodents at least, can impact on satiety (discussed later in more detail) (Cani et al. 2009).

Turnbaugh et al. (2008) found that a high-sugar, high-fat Western-style diet leads to a "bloom" in Mollicutes class of the Firmicutes, reducing the Firmicutes community species richness, together with concomitant reduction in other bacterial groups including the Bacteroidetes. KEGG pathway metabolic reconstruction, using metagenomic sequencing of the whole cecal microbiota, revealed that the Mollicutes have the ability to import the refined sugars characterizing the Western diet, such as glucose, fructose, and sucrose and to use them to produce SCFA.

Recently, Murphy et al. (2010) observed that feeding mice a high-fat diet also causes the increased Firmicutes and reduced Bacteroidetes obese-type microbiota described previously by Turnbaugh, Ley, and Gordon in $o b / o b$ mice and in obese humans. In both wild-type and $o b / o b$ mice, Murphy found that high-fat feeding induced obesity and an obese-type microbiota. Surprisingly, despite an initial increased dietary energy conversion by the microbiota in obese animals, in both $o b / o b$ and high-fat fed wild-type animals, energy harvesting as measured by SCFA production in the cecum and energy content of feces appeared to be divorced from microbiota profile after prolonged exposure to the experimental diet. Fecal energy (as measured by bomb calorimetry) and concentrations of fecal acetate, quantitatively the main short-chain fatty acid produced by the gut microbiota, decreased in both $o b / o b$ animals and obese high-fat fed animals between weeks 7 and 15 of the experiment, while in lean animals, fecal energy content and concentrations of SCFA remained stable.

\section{Evidence from human studies}

The human gut microbiota also appears modified in obesity. A group of 12 obese human subjects showed a gut microbiota highly populated by Firmicutes accompanied by lower abundance of Bacteroidetes and a diet-induced modulation of this obese-type microbiota profile shifting toward higher relative abundance of Bacteroides and decreased abundance 
of Firmicutes upon weight loss with low-calorie diets (either because of fat reduction or carbohydrate reduction) (Ley et al. 2006). Bacteroidetes abundance was in direct correlation with the body weight loss percentage and not with the change of calorie content of the diets. Although each individual was unique in terms of bacterial species populating their intestine, the dominance of Firmicutes and Bacteroidetes was maintained. In agreement with this study, Turnbaugh et al. (2009a, b) and later Nadal et al. (2009) also observed the relatively lower abundance of Bacteroidetes accompanied by a greater relative abundance of Firmicutes in the gut microbiota of obese humans. In addition, the Bacteroidetes populations showed a reduced heterogeneity in the obese gut microbiota (Turnbaugh et al. 2009a). The obese microbiota was enriched for genes encoding energy harvesting-related enzymes. Dominance of Firmicutes was observed in both obese and normal weight groups in a recent human study by Zhang et al. (2009). The obese gut microbiota had a relatively increased abundance of the Bacteroidetes family Prevotellacee, which are important $\mathrm{H}_{2}$ producers. The Archae, mostly from the Methanobacteriales order, were also significantly more abundant in these obese subjects compared with lean. Other than showing a clearly distinct gut microbiota, the obese subjects were populated by a $\mathrm{H}_{2}$-producing- $\mathrm{H}_{2}$-consuming consortium that was hypothesized to contribute significantly in the obese process through increased energy yield from non-digestible dietary components. Armougom et al. (2009) found that a group of obese patients had lower Bacteroidetes, but also Firmicutes compared with the lean controls, and that elevated abundance of Lactobacillus species within the Firmicutes was characteristic of obesity. In adolescents (average age 15), the Firmicutes Clostridium histolyticum, C. lituseburense, and E. rectale-C. coccoides diminished, while Bacterioides/ Prevotella increased after a weight loss of more than $4 \mathrm{~kg}$ (Nadal et al. 2009). Also in obese adolescents, Santacruz et al. (2009) revealed that following a low-calorie diet designed for weight loss, those individuals $(n=23)$ who lost the most weight had a distinct gut microbiota compared with those who were less successful in weight loss. Subjects in the high weight loss group (weight loss higher than $4 \mathrm{~kg}$ ) had a higher average count of total fecal bacteria before dietary intervention compared with the low-weight loss group, characterized by higher numbers of Bacterioides fragilis, Clostridium leptum, and Bifidobacterium catenulatum, together with a lower numbers of C. coccoides, Lactobacillus, Bifidobacterium, B. breve, and B. bifidum as determined by qPCR. Thus, it appears that the composition of the gut microbiota in obesity can impact on weight loss in humans following low-calorie diets and contribute to "success" rates on an individual basis, where success rates for weight-reducing diets are typically low, about $15 \%$ (Ayyad and Andersen 2000).
Other studies have failed to record an association between low abundance of Bacteriodetes within the gut microbiota and obesity in humans. In fact, a higher count of Bacterioides, together with Clostridium and Staphylococcus, was recorded in overweight women, in comparison with the lean women during pregnancy (Collado et al. 2008) or in a group of overweight/obese humans compared with the lean subjects who were populated by Methanobrevibacter (Schwiertz et al. 2010). The same overweight/ obese group also showed higher fecal concentrations of total SCFA, in particular propionate, compared with the lean control group. A link between obesity and carriage of Staphylococcus aureus in feces was noted in a group of obese children (Kalliomaki et al. 2008) whose infant feces contained higher numbers of $S$. aureus than that of lean children. The same study also revealed higher bifidobacterial counts in the infant feces of those childen who upon reaching the age of 7 were within the normal weight range.

Bifidobacteria appeared to be sensitive to carbohydrate dietary intake since their count decreased in obese patients after either high-protein, medium carbohydrate or high protein, low carbohydrate (Duncan et al. 2007). Together with reduced bifidobacterial counts, a significant decrease in total SCFA, particularly acetate, butyrate, and valerate, concentrations in feces was measured after decreasing the carbohydrate intake in these obese subjects. The same dietary intervention showed that Roseburia and Eubacterium numbers decreased in feces and this too was correlated with the deceased dietary carbohydrate even if the population level of the clostridial cluster XIVa group did not appear to be affected. Roseburia and Eubacterium group were also shown to be positively correlated with weight loss (Sotos et al. 2008). Both these bacterial groups play important roles in the production and interspecies crossfeeding interactions, which determine final concentrations and relative proportions of the different SCFA in feces.

As mentioned earlier, Murphy et al. (2010) studied the relative impact of genetically induced obesity (in the $o b / o b$ mouse model) and diet-induced obesity (wild-type mice fed a high-fat diet) on the gut microbiota and its metabolic output. They confirmed a progressive increase in the relative abundance of Firmicutes in both $o b / o b$ and high-fat-fed wild-type animals observed previously by the Gordon group. In genetically obese animals, the phylum Bacteroidetes abundance decreased over time. In terms of "energy harvesting" by the gut microbiota, ob/ob animals after 7 weeks (but not 11 or 15 weeks) showed lower fecal energy content than the other groups but also produced more feces. No difference in fecal energy output as determined by bomb calorimetry was observed between the wild-type animals on different diets. SCFA production decreased over time in all groups, with higher cecal concentrations generally observed in the $o b / o b$ and high-fat-fed 
animals. Although propionate and butyrate concentrations were not determined in feces due to assay sensitivity, acetate was always higher in the genetically obese animals. This in part agrees with Turnbaugh's observation that $o b / o b$ animals display reduced fecal energy content but elevated cecal SCFA concentrations as a result of enhanced energyharvesting potential of the obese gut microbiota (Turnbaugh et al. 2006) and observations in other human obese/lean comparison studies. Schwiertz et al. (2010) reported that in a comparative study of 30 lean, 35 overweight, and 33 obese human subjects, fecal SCFA concentrations were elevated in the obese in agreement with the observations in $o b / o b$ mice, but that the established obese-type microbiota Firmicutes/Bacteroidetes ratio was reversed in obese humans with Bacteroidetes being more abundant in the obese compared with lean subjects. Brinkworth et al. (2009) investigated the impact of 8 weeks dietary intervention with two very different energy-restrictive diets designed to induce weight loss (a low-carbohydrate, high-fat diet and a low-fat, high-carbohydrate, high-fiber diet) on the gut microbiota and their metabolic activity in overweight and obese individuals. Subjects on the low-carbohydrate highfat diet had lower fecal output, lower fecal concentrations of total SCFA and butyrate, and reduced numbers of fecal bifidobacteria compared with subjects on the high-carbohydrate and fiber, low-fat diet. The authors considered this low-carbohydrate, high-fat microbiota profile a detrimental modulation of the gut microbiota, and one possible contributory to gastrointestinal disease. However, these dietinduced changes within the gut microbiome of obese individuals occurred either under uncontrolled dietary environments (Schwiertz et al. 2010) or energy-restrictive conditions over a relatively short period of time (Brinkworth et al. 2009). It would be interesting to determine whether a similar modulation of fecal SCFA excretion occurs in overweight individuals on high-calorie or caloriesufficient controlled diets of varying macronutrient composition over a longer period of time.

In summation, even if a consistent specific pattern in the bacterial populations has not been found in all obese versus lean human studies, in most studies, bacterial profiles of the obese gut microbiota were different to those found in the lean individuals, and differences were observed in bacterial populations or microbial metabolites upon dietary intervention with diets designed to modify body weight. This may not be surprising considering that many metabolic activities are shared between diverse bacterial species (e.g., many different groups of bacteria are involved in both carbohydrate fermentation and the deconjugation of bile acids and the enterohepatic circulation of bile acids). For a given individual, what is important is that the gut microbiota appears to be altered in obesity or on obese-type diets, that this aberrant microbiota can impact on different physiological mechanisms regulating body energy metabolism, lipid homeostasis, and immune function, and that dietary components can be used to modulate this aberrant microbiota and their interactions with the host. However, despite strong data from animal studies, the ability of diet to modulate gut microbial activities for improved human energy homeostasis remains to be confirmed in well-powered human intervention studies.

\section{Cellular mechanisms linking the colonic microbiota, fermentation, and mammalian energy metabolism}

On analysis of data from animal experiments, germ-free, genetic models of obesity and nutritional models of obesity alike, and from the limited number of human studies, it is difficult to get a coherent picture of whether the gut microbiota plays an etiological role in the epidemic of new obesity sweeping the developed world or whether it is a consequence of diet in obesity, or both. However, these studies clearly illustrate the importance of the microbiotal metabolic output and direct physiological interactions at the cellular level between microorganisms and mammals in global energy metabolism. Animal studies in particular have shown that the gut microbiota impacts on a number of important physiological processes and metabolic pathways responsible for regulating mammalian energy homeostasis that either alone or more likely in combination contribute to regulating body composition and human obesity.

Increased glucose uptake from the small intestine

Germ-free animal studies have shown that intestinal colonization with the gut microbiota or the common anaerobic human commensal, B. thetaiotaomicron, induces the expression of sodium/glucose transporter-1 (SGLT1) in the small intestine (Hooper et al. 2001). This results in a doubling of glucose absorption from the intestine of these ex-germ-free animals. In addition, these studies also showed an increase in vasculature and blood supply to the intestine in ex-germ-free animals, showing that colonization of the intestine with commensal bacteria is an important step in mucosal maturation (Stappenbeck et al. 2002). Increased glucose absorption as a result of intestinal colonization and mucosal maturation may therefore be particularly important in infants, where microbial colonization of the sterile gut occurs shortly after birth.

Contribution of SCFA directly to energy metabolism

It has been estimated that SCFA produced in the colon principally upon fermentation of non-digestible carbohydrates by the resident microbiota contributes about $10 \%$ of 
daily energy requirements in man (Macfarlane and Gibson 1997). The main SCFA are acetate, propionate, and butyrate, in that order. Butyrate is an important energy source for the colonic mucosa and plays a role in epigenetic control of gene expression through the inhibition of histone deacetylase, thus modifying DNA methylation (Meijer et al. 2010). As described below, acetate acts as a substrate for hepatic de novo lipogenesis via acetyl-coA and fatty acid synthase (FAS), while propionate down-regulates lipogenesis. Additionally, acetate also acts as a substrate for hepatic cholesterol biosynthesis, a process that in rats at least is blocked by inhibition of the cholesterol biosynthesis ratelimiting enzyme, 3-hydroxy-3-methylglutaryl coenzyme A (HMG-CoA) by propionate. Thus, the ratio of acetate/propionate produced, mainly from carbohydrate fermentation in the colon, plays a critical role in regulating lipid and cholesterol metabolism in our bodies (Favier et al. 1995).

De novo lipogenesis in the liver

Hepatic de novo lipogenesis is the process whereby the body converts excess glucose into lipids for storage. Increased glucose absorption from the intestine as a result of conventionalization of germ-free animals leads to increased hepatic lipogenesis through the activation of carbohydrate response element-binding protein (ChREBP)-activated genes or by increased insulin concentrations activating sterol response element-binding protein-1 (SREBP-1). Colonization also leads to an up-regulation of acetyl-CoA carboxylase (Acc1) and fatty acid synthase (FAS) enzymes involved in lipogenesis (Bäckhed et al. 2004). In conventional animals and in human hepatocytes, SCFA have been shown to impact on lipogenesis, with acetate as lipogenic substrate and propionate inhibiting lipogenesis through reduced expression of FAS in particular. A number of factors impact on the ratio of acetate to propionate and subsequent regulation of de novo lipogenesis including better absorption of propionate across the colonic mucosa compared with acetate, and the fact that the liver appears to preferentially clear propionate from the portal vein compared with acetate $(90 \%$ of propionate in the portal vein is removed following one pass through the liver compared with $75 \%$ of portal acetate) and that the fermentation of different fibers or non-digestible carbohydrates by the colonic microbiota have been shown to give different concentrations of SCFA in vitro and in acute feeding studies in healthy individuals (Dankert et al. 1981; Peters et al. 1992; Vogt et al. 2004). Thus, high concentrations of propionate regulate both acetate uptake from the colon and fas gene expression in the liver, controlling de novo lipogenesis at both substrate supply and enzyme activity levels (Agheli et al. 1998; Daubioul et al. 2002; Fava et al. 2006).

\section{Fat storage and serum triglycerides}

The gut microbiota has been suggested to alter fat storage through the regulation of FIAF (fasting-induced adipose factor, also known as angiopoietin-like 4 protein, ANGPTL4, or PPAR $\gamma$ angiopoietin-related PGAR), an inhibitor of lipoprotein lipase (LPL). FIAF, produced by brown and white fat, liver and intestine, inhibits LPL, regulating fatty acid oxidation in both muscle and adipose tissue. LPL promotes release of fatty acids from circulating chylomicrons and VLDL, which results in their storage as triglycerides in the adipose tissue. FIAF inhibition of LPL therefore reduces fat storage. FIAF is suppressed in germfree animals colonized with either a conventional mouse gut microbiota or B. thetaiotaomicron (Bäckhed et al. 2004). Thus, it has been proposed that suppression of FIAF in conventionalized germ-free animals may be a mechanism by which conventionalization leads to increased fat deposition and obesity. Fleissner et al. (2010) on the contrary found that intestinal production of Fiaf/Angptl4 did not play a role in gut microbiota-mediated effects on fat storage. Intestinal expression of Fiaf/Angptl4 was elevated in both germ-free and conventional $\mathrm{C} 3 \mathrm{H}$ mice on either high-fat or Western-style diets, without effecting circulating levels of the protein. In this report, germ-free mice on a high-fat diet had higher body weight than conventional animals on the same diet, in contrast to earlier reports of obesity and increased body fat induced by conventionalization. However, the authors did note dramatic effects of diet on the gut microbiota, with the microbiota of conventional mice fed either high-fat or Western-style diets showing a relative enrichment for Firmicutes, mainly due to high abundance of a single family, the Erysipelotrichaceae, and lower relative abundance of Bacteroidetes, as was observed by Ley, Bäckhed, Turnbaugh in the Gordon group (Ley et al. 2005, 2006; Turnbaugh et al. 2006, 2008, 2009a; Turnbaugh and Gordon 2009). Recently, the probiotic strain Lactobacillus paracasei ssp. paracasei $\mathrm{F} 19$, a Firmicutes originally isolated from the human small intestine, was shown to reduce fat storage in mice fed a high-fat diet $(20 \%)$ through increased circulating levels of FIAF. Mice supplemented with $L$. paracase $i$ F19 showed a significant increase in lipoprotein VLDL triglyceride load but no change in cholesterol profiles (TC, VLDL, LDL, HDL). However, total body fat was significantly reduced in probiotic-supplemented animals as measured by MRI, and circulating levels of FIAF were significantly higher in this group. Co-culture of the intestinal cell line HCT116 with selected gut bacteria showed that the probiotic lactobacilli, L. rhamnosus GG and L. paracasei F19 and to a lesser extent the Bifidobacterium animalis subsp. lactis Bb12, stimulated FIAF gene expression after $6 \mathrm{~h}$ unlike the commensal Bacteroides thetaiotaomicron. Bacteroides and 
bifidobacteria are anaerobic bacteria and their relative failure to induce FIAF may indicate a necessity for active growth and metabolic activity. F19 also stimulated FIAF production in cell lines LoVo, HT29, and SW480. The active factor appeared to be present in cell-free supernatants of F19 and to be resistant to heat inactivation. Expression of FIAF appeared to be regulated by PPAR $\gamma$ and $\operatorname{PPAR} \alpha$, as siRNA to these transcription factors markedly reduced F19-induced gene expression. Colonization of germ-free animals with F19 also resulted in increased circulating ANGPTL4. Suppression of these receptors did not always compromise FIAF expression as also observed previously by Bäckhed et al. (2004).

Enterohepatic circulation of bile acids

Bile acids are released into the small intestine upon ingestion of fatty meals to aid lipid uptake via emulsification and micelle formation. These cholesterol derivatives are reabsorbed in the ileum but if deconjugated or hydroxylated by the gut microbiota are rendered less hydrophobic limiting their absorption across the mucosa and driving their excretion in feces. Bile acids excreted in feces must be replaced by new bile acids synthesized from cholesterol in the liver and can thus impact on blood cholesterol levels. Certain diets, including those supplemented or naturally high in fiber or polyphenols, can increase excretion of bile acids, although the relative contribution of direct bile acid binding in the small intestine and subsequent protection from re-absorption or up-regulation of the deconjugative activities of the gut microbota remains to be determined. Fukasawa et al. (2010) investigated the mechanisms underpinning the observed hypolipidemic effect of the prebiotic, short-chain fructooligosaccharides or FOS. Using a nutrigenomicsbased approach, these authors examined hepatic gene expression in rats fed a diet supplemented with the FOS for 2 weeks compared with an isoenergetic diet. DNA microarray analysis of hepatic gene expression revealed modified regulation of genes involved in lipid metabolism, organic acid metabolism, amino acid and derivative metabolic processes, and genes related to proliferation, differentiation, and programmed cell death. Hepatic expression of proliferator-activated receptor- $\alpha$ (PPAR- $\alpha$ ) and farnesoid X receptor (FXR) ligand-activated transcription factors was activated. These transcription factors are involved in fatty acid oxidation, lipoprotein, bile acid and amino acid metabolism, glucose homeostasis, and bile acid homeostasis, lipoprotein and glucose metabolism, respectively. PPAR $-\alpha$ is thought to be activated by endogenous longchain unsaturated fatty acids, eicosanoids and prostaglandins (themselves regulated by SCFA), and dietary fatty acids, including conjugated linoleic acid (CLA), and FXR is a bile acid receptor. Thus, prebiotic modulation of the gut microbiota may have wrought these changes in hepatic gene expression and therefore modified lipid, glucose, and bile acid homeostasis by the production of particular profiles of bile acids and their interaction with the transcription factor FXR or upon SCFA production via PPAR- $\alpha$. FOS and other fructans, specifically oligofructose and inulin, have been confirmed to improve blood lipid profiles in hyperlipidemic subjects, in a recent metanalysis of human studies (Brighenti 2007).

Modulating mammalian lipid and energy metabolism using probiotic microorganisms

Although yoghurt and milk drinks fermented with lactic acid bacteria have long been studied for their ability to regulate human body weight among other health effects, the scientific evidence of efficacy is equivocal. One recent human intervention in 87 overweight individuals (24.2$30.7 \mathrm{~kg} / \mathrm{m}^{2}$, abdominal visceral fat area $\left(81.2-178.5 \mathrm{~cm}^{2}\right)$ found that $200 \mathrm{~g} /$ day of a probiotic (Lactobacillus gasseri SBT2055) fermented milk significantly reduced body weight, abdominal fat area, and subcutaneous fat area, while no change in these parameters was observed with a control non-probiotic fermented milk over a 12-week period. High molecular weight adiponectin was elevated in the serum of both groups after fermented milk intervention (Kadooka et al. 2010). Similarly, in a 10-year follow-up study, Luoto et al. (2010) found that perinatal probiotic intervention with Lactobacillus rhamnsus GG was associated with restraining of excessive infant weight gain during the first years of life in 159 mother/child pairings.

Yin et al. (2010) examined the impact of four bifidobacterial strains of human origin in a rat model of dietinduced obesity. Compared with rats on a high-fat diet without probiotic supplementation, dietary supplementation with one of the bifidobacterial strains reduced body weight, another increased body weight, while two other bifidobacterial strains had no effect on body weight. Interestingly, all bifidobacterial strains showed improvements in lipid and cholesterol markers, with reduced serum and hepatic triglycerides and at least a trend toward reduced serum and liver cholesterol. Adding bifidobacteria to the diet did not effect blood glucose or insulin. Importantly, this study shows that the anti-obesity effects of probiotics may be strain-specific (going some way to explain lack of effect in body weight management in certain studies).

Wall et al. (2009) found that enteric microbiota or bacteria of enteric origin could alter fatty acid composition in murine and porcine liver and adipose tissue when added as feed along with dietary fat. Oral administration of a 
probiotic Bifidobacterium breve strain capable of producing conjugated linoleic acid (CLA) from dietary linoleic acid could influence fat composition in the different mammalian tissues. BALB/c mice, immunodeficient mice (SCID), and weanling pigs were fed linoleic acid-supplemented diets with or without $B$. breve NCIMB 702258. The combination of dietary linoleic acid and probiotic microorganism led to increased cis-9, trans-11 CLA in the livers of mice and pigs, and higher concentrations of PUFA omega-3 (n-3) fatty acids eicosapentaenoic acid and docosahexaenoic acids were found in adipose tissue. Mucosal inflammatory markers (including TNF-alpha, IL-6, and INF-gamma) were reduced in pigs upon probiotic/ linoleic acid feeding compared with control linoleic acid diet, which may be of relevance in obesity and the diseases of obesity. CLA has also been shown to alleviate nonalcoholic fatty liver disease (Nagao et al. 2005). In an earlier study, Lee et al. (2006), with the human-derived probiotic Lactobacillus rhamnosus PL60 strain that produces t10, c12-CLA, reduced body weight without reducing energy intake in high fat-induced obese mice. Probiotic dietary supplementation reduced white fat mass and there appeared to be a normalization of hepatic steatosis. These studies show that the most likely explanation for probioticinduced regulation of body fat involves modulation of bile acid and cholesterol metabolism under a prevailing high-fat dietary environment possibly through the up-regulation of PPAR and FXR transcription factors in the liver. CLA is an known ligand of PPAR transcription factors involved in the regulation of nutritional-induced inflammatory processes, and probiotic modulation of the enterohepatic circulation of bile acids or binding of cholesterol in the intestine and subsequent increased fecal excretion may impact on activation of the bile acid-induced FXR transcription factor. This in turn would impact on downstream gene expression under FXR regulation involved in lipid absorption and de novo lipogenesis. However, these studies need to be confirmed, and few data in humans exists.

\section{Muscle fatty acid oxidation and thermogenesis}

Conventionalization of germ-free animals shows that the intestinal microbiota reduces the expression of adenosine monophosphate-activated protein kinase (AMPK) in the liver and muscle, which plays a key role in fatty acid betaoxidation (Bäckhed et al. 2007). Muscle tissue in particular exhibits increased rates of fatty acid oxidation in germ-free animals fed a Western-style diet compared with conventional counterparts, with elevated AMP, AMPK, and phosphorylated acetyl-CoA carboxylase leading to increased carnitine palmitoyl transferase activity (Bäckhed et al. 2007). This leads to increased fatty acid oxidation in muscle and may help maintain lean phenotype in germ-free animals exposed to a high-fat/Western-style diet. Under natural ecological conditions, where the intestine is colonized by a gut microbiota from birth, oral acetate, or vinegar, ingestion has long been associated with improvements in blood lipid, cholesterol, and glucose levels and in the regulation of satiety. Recently, Kondo et al. (2009) confirmed that acetate delivered by oral gavage to high-fat fed mice inhibited accumulation of body fat and hepatic fat deposition without changing food intake. They found that acetate induced hepatic gene expression of $\operatorname{PPAR} \alpha$ and of fatty acid oxidation and thermogenesisrelated proteins, acetyl-CoA oxidase, carnitine palmitoyl transferase-I (CPT-1), and uncoupling protein-2 (UCP-2) via a $\alpha 2-5^{\prime}$ AMP-activated protein kinase mediated mechanism. As acetate is the main SCFA produced from fermentation of carbohydrate in the colon, it would be interesting to see whether similar results are mediated upon fiber or prebiotic up-regulation of colonic fermentation. Gao et al. (2009) found that supplementing the diet of highfat fed mice with sodium butyrate $(5 \% \mathrm{w} / \mathrm{w})$ reduced body weight in obese animals, maintained weight in lean animals and protected against insulin resistance. Butyrate enhanced adaptive thermogenesis, a key regulator of energy homeostasis and fatty acid oxidation. Brown adipose tissue (BAT) is responsible for adaptive thermogenesis in response to diet. Adipocyte size was smaller in BAT in the butyrate-fed group, while gene expression and protein levels of two key genes involved in thermogenesis, PGC$1 \alpha$ and UCP-1, were upregulated. Butyrate supplementation also increased the proportion of type I oxidative fibers in muscle tissue, which are relatively rich in mitochondria, store energy as triglycerides and are more resistant to fatigue. AMPK and p38 were activated in the liver of butyrate-fed animals suggesting that these two kinases may contribute to the increased PGC- $1 \alpha$ activity induced by butyrate since they are known to extend PGC- $1 \alpha$ half-life through phosphorylation and enhance its transcription activity. Fatty acid oxidation in muscle mitochondria increased in the butyrate-fed animals as measured by the oxidation of ${ }^{14} \mathrm{C}$-labeled palmitic acid with concomitant increased expression of PPAR- $\delta$, a promoter of fatty acid oxidation in muscle, and PGC- $1 \alpha$ controlled genes CPT1b and COX-1 (cytochrome c oxidase I). In a second experiment, butyrate was also found to reduce body weight and body fat percentage, and to improve markers of insulin resistance when fed to obese animals. Together, these data suggest a possible role for butyrate in controlling body weight and markers of the metabolic syndrome, mainly through increased energy expenditure and thermogenesis. Butyrate in this case was delivered directly in the diet at high levels and it remains to be seen whether similar up-regulation of thermogenesis is achievable through increased colonic fermentation of fiber and indeed in 
humans. However, recent microbial ecology studies comparing the gut microbiota and colonic fermentation between groups of individuals following high-fiber "traditional" whole-plant food diets compared with Westernstyle low-fiber diets are showing that high dietary fiber diets are associated with considerably higher fecal SCFA concentrations. For example, De Filippo et al. (2010) found significantly lower concentrations of total SCFA in children in Italy following a Western-style low-fiber diet compared with age-matched children in Burkina Faso following a more traditional high-fiber African diet. Concentrations of fecal propionate and butyrate were nearly four times higher in the Burkina Faso children. Interestingly, fecal microbiota $16 \mathrm{~S}$ rRNA community sequencing analysis showed that the Enterobacteriaceae appeared to be in significantly higher abundance in the European children, while the African children had higher abundance of Actinobacteria (mainly bifidobacteria) and Bacteroidetes and a relative depletion in Firmicutes. These studies also support epidemiological data showing an inverse association between fiber intake and obesity.

SCFA regulate satiety and thus food intake, through control of gut hormone expression

SCFA produced upon carbohydrate fermentation in the colon regulate gut hormones including peptide YY (PYY) and glucagon-like peptide (GLP), which in turn regulate production and release of digestive enzymes and satiety, our feeling of fullness. The human brain and gut are connected via an endocrine network of signaling hormones that oversees energy homeostasis, regulating feelings of hunger and satiety, regulating food intake and transit times through the different sections of the gastrointestinal tract. The pancreas secretes insulin in reply to GLP-1, promoting satiety and slowing gastric emptying. GLP-1 and PYY are expressed mainly in intestinal L cells and are released systemically in response to G-coupled receptors (Darzi et al. 2011). Two G-coupled receptors have been identified, which have SCFA as ligands, FFA2 and FFA3 (formally GPR43 and GPR41, respectively) (Stoddart et al. 2008). Although both are activated by all three major SCFA, FFA3 is preferentially activated by propionate and butyrate, and the receptors are expressed in a range of human tissues including the intestinal epithelium, immune cells including neutrophils and adipocytes (Darzi et al. 2011). Propionate has been shown to induce circulating leptin in mice via activation of FFA3 in adipocytes (Xiong et al. 2004). In the colon, FFA 2 and FFA 3 are found in L cells together with the anorexigenic gut hormones, PYY, which regulates intestinal motility and thus the availability of food for digestion and nutrient absorption from the gut, and GLP-1 excreted by L cells, which regulates satiety. In rats and pigs, luminal administration of SCFA solutions induce PYY and reduce upper gut motility (Cherbut et al. 1998; Cuche et al. 2000) implicating FFA3 in gut hormone regulated intestinal motility and satiety control.

The activity of the endocrine cells of the intestine also appears to be under the influence of the microbiota resident in the intestine of zebrafish (Bates et al. 2006) and rats (Uribe et al. 1994; Cani et al. 2007b). When oligofructose has been introduced with the diet, a contemporary increase in bifidobacteria and $\mathrm{L}$ cells has been observed in the rat colon. Similarly, prebiotic carbohydrates have been shown to modify the gut microbiota and increase GLP-1 and 2 production in $o b / o b$ mice (Cani et al. 2009). In addition, gut hormone PYY has been shown to be released in response to gut microbiota metabolic stimulus. Intestinal permeability is underregulated by GLP-2, which also upregulates glucose transport from the intestine (Drucker 1999).

Parnell and Reimer (2009) showed that high-level $(21 \mathrm{~g} /$ day $)$ oligofructose intake could reduce body weight over a 12-week period in overweight healthy adults $(n=24)$ compared with a placebo group. This weight reduction was accompanied by reduced ghrelin and increased production of PYY but not GLP-1, in the oligofructose group compared with control, consistent with reduced food intake in the prebiotic-supplemented group. Prebiotic intervention also improved fasting glucose and insulin levels. The same authors later showed that oligofructose at 10 and 20\% diet reduces blood cholesterol and triglycerides via upregulation of cholesterol excretion via bile and inhibited TAG accumulation in the liver in a FAS-independent manner (Parnell and Reimer 2010). So et al. (2007) found that resistant starch (RS), starch that resists digestion in the upper gut but acts as a main carbohydrate source for colonic fermentation and SCFA production, could impact on satiety and body composition in rats compared with non-RS, which is readily digested and absorbed in the upper gut and therefore does not usually contribute greatly to colonic fermentation. The Authors used ${ }^{1} \mathrm{H}$-magnetic resonance imaging (MRI) to measure whole body composition and fat deposition in the liver and manganeseenhanced MRI to investigate hypothalamic neural activity involved in appetite control in response to up-regulation of colonic fermentation by dietary RS. Mice on either diet had similar body weights after the 8-week intervention but significantly different fat distribution, with the RS-fed animals having lower total body adiposity, subcutaneous and visceral fat, and intrahepatocellular lipids than the animals fed the RS diet. Similarly, plasma leptin, adiponectin (an inflammatory molecule produced by adipocytes), and blood insulin/glucose ratio were all significantly lower in the RS fed animals. RS-fed animals had larger adipocytes with lower insulin-stimulated glucose uptake than 
adipocytes from the RS-fed animals, both indicative of obesity and metabolic disease. Manganese-enhanced MRI of the hypothalamus appetite centers of these animals showed that ventromedial hypothalamic nucleus and paraventricular hypothalamic nucleus had significantly greater uptake of $\mathrm{Mn}^{2+}$ in the RS-fed animals compared with the RS-fed animals, indicating that RS feeding decreased neuronal activity responsible for appetite control, enhancing satiety in these animals. Thus, SCFA produced by the colonic microbiota appear to be both energy source and signaling molecules important for regulating food intake and gastrointestinal transit times.

Gut microbiota, "leaky-gut", and inflammation

Intestinal mucosal permeability is in large part governed by the extent to which epithelial cells adhere to each other. This occurs through a complex system of junction proteins (tight junction, adherens junction, gap junction, and desmosomes). In particular, the tight junctions are made of a heteropolymer membrane integral proteins including occludine and claudin (Tsukita 2001), ZO-1 (Stevenson et al. 1986). The junction, in particular the tight junction barrier, is responsible for charge (cation) and size selectivity paracellular mechanisms modulating the passage of the intestinal contents (microbes and metabolites) into the blood stream. If the barrier mechanism malfunctions, the gut contents "leak" into the circulatory system. This leads to the passage of pathogens, but also toxins and allergens including LPS (Barbara 2006; Guttman et al. 2006) together with other metabolic products, which can affect other distant organ functions (Maes 2008; Maes and Leunis 2008; Sandek et al. 2008; Vaarala et al. 2008). Butyrate has been shown to reduce mucosal permeability, increasing transepithelial electrical resistance, and impeding PEG translocation in heat-damaged rat colon (Venkatraman et al. 1999); therefore, colonic bacterial fermentation leading to high production of butyrate has been suggested to exert a positive effect on restoring mucosal barrier function. In addition, certain members of the gut microbiota, including strains of Lactobacillus plantarum (Anderson et al. 2010), Escherichia coli (Ukena et al. 2007), and Bifidobacterium lactis (Putaala et al. 2008), are capable of directly enhancing the expression of tight junction proteins occludine and $\mathrm{ZO}-1$, leading to fortification of the intestinal barrier.

Diabetes, the metabolic syndrome, and obesity are metabolic diseases characterized by low-grade systemic inflammation (Hotamisligil and Erbay 2008). Immune responses are part of the complex interplay between different host physiological processes that respond to host nutritional stimuli. Cytokines like tumor necrosis factor- $\alpha$ (TNF- $\alpha$ ), IL-1, and IL-6 are associated with the inflammatory processes that occur in obesity and lead to the development of insulin resistance (Hotamisligil et al. 1996). Bacterial LPS is an important structural component of Gram-negative bacterial cell walls, such as those of Bacteroidetes and the Enterobacteriaceae, and is highly inflammatory, being a pathogen-associated molecular pattern recognized by the innate immune system. Cani et al. (2007a) found that mice injected with LPS showed increased weight gain and insulin resistance without effecting the energy intake. They also found that animals fed a high-fat diet showed a similar physiological and inflammatory response and had elevated plasma LPS. The same study showed that mice deficient for the Toll-like receptor 4 (TLR-4) co-receptor CD14 responsible for innate immune system recognition of LPS were protected from LPS, and high-fat diet-induced inflammation, weight gain, and insulin resistance. Serum amyloid A (SAA) proteins have been proposed as mediators of inflammation and metabolism. SAA are elevated in obesity and there is a suggestion that this is in response to LPS (Yang et al. 2006). This protein has been proposed as link between chronic inflammation and obesity. In mice, SAA3 is elevated in both the adipocytes and intestinal cells if bacteria are present. Based on observations in germ-free, conventionally raised, and Myd88 -/- mice, LPS from bacterial cell wall may (Reigstad et al. 2009) activate SAA (and TNF- $\alpha$ ) production from the colonic cells through the signal cascade (Kaway and Akira 2006) TLR4-Myd88-NF- $\kappa$ B, with NF$\kappa \mathrm{B}$ finally regulating the expression of SAA in the nucleus. LPS stimulus could arise from either direct contact with the epithelium cells or by leakage of LPS across the intestinal mucosa. Cani et al. (2007c) demonstrated that mice fed a high-fat diet supplemented with the prebiotic oligofructose had reduced plasma concentrations of the cytokines TNF- $\alpha$, IL-1, and INF- $\gamma$ recognized as tight junction disruption promoters, compared with control animals on high-fat diet alone via up-regulation of GLP-2 production from intestinal L cells as discussed previously. GLP-2 is known to be up-regulated by SCFA. In addition, after observing higher plasma LPS content in humans on energy-rich diets, it has been suggested that a diet rich in fat may cause metabolic inflammation by contributing to uptake of LPS from the intestinal lumen (Amar et al. 2008; Cani et al. 2007c). This mechanism was clarified by Ghoshal et al. (2009) showing that dietary fat translocated from the intestine to the blood stream as triglycerides by the chylomicrons also carries LPS from the intestine.

The high-fat diets have also been shown to influence the composition of the gut microbiota (as discussed previously). de La Serre et al. (2010) recently determined that it is the appearance of inflammation that leads to with hyperphagia and obesity in rats on high-fat diets rather than changes within the composition of the gut microbiota per se. Using the Spargue-Dawley outbred rats that display 
heterogeneity in obese phenotype on high-fat diets, with some individuals being prone to obesity (DIO-P) and others resistant to obesity (DIO-R), the authors found that high-fat feeding had a dramatic and similar impact on the composition of the gut microbiota in both rat phenotypes compared with rats on a low-fat diet. High-fat feeding increased the relative proportions of both Bacteroidiales and Clostridiales irrespective of obesity and mucosal inflammation (de La Serre et al. 2010). Obese animals did, however, show elevated Enterobacteriaceae (important producers of inflammatory LPS) compared with both obesity-resistant high-fat-fed animals and low-fat-fed animals. Hyperphagia, significantly higher body weight, and adiposity index were observed in the DIO-P animals compared with DIO-R and control low-fat-fed animals. Obesity only occurred upon up-regulation of mucosal inflammatory markers, myeloperoxidase activity as a measure of inflammation and neutrophil infiltration of ileal mucosa and TLR4 activation as measured by immunolocalization of the TLR4/MD2 complex within and along the basolateral region of enterocytes indicating bacterial translocation and plasma LPS elevation. Intestinal alkaline phosphatase (IAP) dephosphorylates LPS reducing the toxicity of the lipid A region of the LPS molecule and is recognized as a local mucosal defence factor possibly acting through regulation of TLR4 recognition of LPS from the microbiota (Chen et al. 2011). In the DIO-P animals, IAP activity was reduced in the duodenal mucosa after 8 weeks of high-fat feeding, while both ileal p-MLC expression and cytoplasmic occludin immunoreactivity were significantly increased in DIO-P after 12 weeks high fat compared with the other groups. Although not measured in this present study, IAP expression is inhibited by inflammatory cytokines IL- $1 \beta$ and TNF- $\alpha$ (known to be elevated in metabolic endotoxemia and obesity) and is induced by the SCFA butyrate (Malo et al. 2006), likely to be in short supply in high-fat lowfermentable fiber diets, such as the one used by de La Serre et al. (2010) Gut permeability as measured by FITC-labeled dextran appearance in plasma was observed in DIO-P highfat-fed animals after 10 weeks. Together, these data point toward a high-fat-induced modulation of the gut microbiota, which in obesity prone animals, leads to mucosal inflammation, compromises mucosal defences and increases gut permeability and elevates plasma LPS, which then goes on to trigger body weight gain and obesity. The trigger of mucosal inflammation in these animals, which then compromises the mucosal barrier, remains to be determined, although modified IAP expression in response to diet or microbiota modulation (e.g., SCFA concentrations) and increased inflammatory response to LPS either at the mucosal surface or upon carriage across the gut wall by dietary fat are promising candidates.

\section{Conclusions}

Although most studies show differences in the composition of the gut microbiota between lean and obese individuals, a clear "obese-type" microbiota fingerprint or profile does not appear to be defined at the phylogenetic level. Although some of this discrepancy may be accounted for by methodological differences, for example, deep $16 \mathrm{~S}$ rRNA gene community sequencing as opposed to more direct enumeration methods like qPCR and FISH, it is possible that this heterogeneity may also reflect the fact that metabolic function within a given gut microbiome may be commonly shared between different bacterial species, even distantly related bacterial species.

The interactions between the gut microbiota, nutrient intake, energy harvesting, weight gain, and host metabolism appear to be quite intricate. Animal studies have shown that the gut microbiota can increase glucose uptake from the small intestine, produce SCFA directly contribute to energy metabolism, control lipid generation in the liver, control fat storage, and serum triglycerides concentration. The gut microbiota link with the liver metabolism is well established through the enterohepatic circulation of bile acids and their deconjugation in the colon and also modulation of liver metabolic activities and lipid handling by SCFA produced by the gut microbiota upon carbohydrate fermentation in the colon. SCFA also play a role in satiety and control of food intake by regulating the gut hormone expression. Probiotics, in particular the bifidobacteria, and especially Bifidobacterium breve, may influence liver lipid and cholesterol markers and modify the bodies handling of dietary lipids such as linoleic acid. A number of studies also show that this important group of gut bacteria, often considered a marker of a healthy gut microbiota, are inversely associated with obesity. SCFA, pre-, and probiotics are also linked to the regulation and reduction of inflammation in obesity, while high-fat diets have been linked to inflammation through increased LPS leakage from the gut.

Apparent contradiction between germ-free studies (showing that the gut microbiota increases energy recovery from diet and thus contributes to obesity) and studies in conventional animals and humans, which show that upregulation of colonic fiber fermentation can lead to reduced energy intake, body weight control, and protection from the diseases of obesity, may not on second glance be in fact contradictory. The germ-free models describe a xenobiotic situation more akin to early successional development of the gut micobiota and intestinal colonization in infants, where appropriate successional development of the gut microbiota is linked to increased body weight, health in the infant and later in life, especially in breast fed, term infants, 
Table 1 Gut microbiota-obesity links based on experimental evidence (modified from Tuohy et al. 2009b)

\begin{tabular}{|c|c|c|c|c|}
\hline Model & Design & Evidence & Proposed mechanism & References \\
\hline $\begin{array}{l}\text { C57bl6/J } \\
\text { Germ-free } \\
\text { mice }\end{array}$ & $\begin{array}{l}\text { Conventionalization of wild-type } \\
\text { and Fiaf }-/- \text { germ-free mice with } \\
\text { murine gut microbiota or with } \\
\text { Bacteroides tetaiotaomicron }\end{array}$ & $\begin{array}{l}\text { Conventionalization or } \\
\text { monoassociation of germ-free } \\
\text { mice led to increased body fat } \\
\text { with less food intake compared } \\
\text { with germ-free animals }\end{array}$ & $\begin{array}{l}\text { Gut microbiota suppression of Fiaf } \\
\text { and relief of LPL inhibition and a } \\
\text { resulting increased deposition of } \\
\text { triglycerides in adipocytes }\end{array}$ & $\begin{array}{l}\text { Bäckhed et al. } \\
\text { (2004) }\end{array}$ \\
\hline $\begin{array}{l}\mathrm{C} 57 \mathrm{bl6} / \mathrm{J} o b / o b \\
\text { mice }\end{array}$ & $\begin{array}{l}O b / o b \text { versus lean wild-type cecal } \\
16 \mathrm{~S} \text { rRNA gene fragment } \\
\text { sequence }\end{array}$ & $\begin{array}{l}\text { A } 50 \% \text { reduction in the relative } \\
\text { abundance of Bacteroidetes and a } \\
\text { proportional increase in } \\
\text { Firmicutes abundance in obese } \\
\text { gut microbiota compared with the } \\
\text { lean-type microbiota }\end{array}$ & $\begin{array}{l}\text { Lack of functioning leptin and } \\
\text { resultant obesity-modified gut } \\
\text { microbiota enhancing dietary } \\
\text { energy recovery }\end{array}$ & $\begin{array}{l}\text { Ley et al. } \\
\text { (2005) }\end{array}$ \\
\hline Human adults & $\begin{array}{l}\text { 16S rRNA gene sequence library of } \\
\text { gut microbiota in obese subjects } \\
\text { on weight reduction diets (low } \\
\text { carbohydrate or low fat, } n=12 \text { ) }\end{array}$ & $\begin{array}{l}\text { Relative proportion of } \\
\text { Bacteroidetes increased compared } \\
\text { with Fimicutes and correlated } \\
\text { with percentage of weight loss }\end{array}$ & $\begin{array}{l}\text { The gut in obesity exerts ecological } \\
\text { pressure promoting a higher } \\
\text { relative abundance of Firmicutes }\end{array}$ & $\begin{array}{l}\text { Ley et al. } \\
\text { (2006) }\end{array}$ \\
\hline $\begin{array}{l}\text { Germ-free and } \\
o b / o b \\
\text { C57bl6/J } \\
\text { mice }\end{array}$ & $\begin{array}{l}\text { Sequenced metagenome of cecal } \\
o b / o b \text { and lean wild-type mice } \\
\text { sequenced }(n=2)\end{array}$ & $\begin{array}{l}\text { Increased Firmicutes and reduced } \\
\text { Bacteroidetes prevalence in the } \\
\text { obese compared with lean } \\
\text { animals. ob/ob microbiome } \\
\text { enriched in sequences encoding } \\
\text { polysaccharide-degrading } \\
\text { enzymes and other genes involved } \\
\text { in energy recovery from diet }\end{array}$ & $\begin{array}{l}\text { The obese gut microbiota with } \\
\text { enhanced potential to extract } \\
\text { energy from diet }\end{array}$ & $\begin{array}{l}\text { Turnbaugh } \\
\text { et al. (2006) }\end{array}$ \\
\hline $\begin{array}{l}\text { C57bl6/J Mice } \\
\text { and } \\
\text { CD14-/- } \\
\text { mutant strain }\end{array}$ & $\begin{array}{l}\text { Metabolic, inflammatory and } \\
\text { microbiological differences } \\
\text { (FISH) between high-fat-fed } \\
\text { obese or rodent lean chow-fed } \\
\text { mice }\end{array}$ & $\begin{array}{l}\text { High-fat feeding and obesity } \\
\text { decimates intestinal microbiota- } \\
\text { Bacteroides-mouse intestinal } \\
\text { bacteria, Bifidobacterium, and } \\
\text { Eubacterium rectale-Clostridium } \\
\text { coccoides groups all significantly } \\
\text { lower than in control animals }\end{array}$ & $\begin{array}{l}\text { High-fat diet-induced die-off of gut } \\
\text { microbiota leads to elevated } \\
\text { plasma LPS leading to metabolic } \\
\text { endotoxemia, possibly through } \\
\text { compromised mucosal barrier } \\
\text { function }\end{array}$ & $\begin{array}{c}\text { Cani et al. } \\
(2007 \mathrm{c})\end{array}$ \\
\hline C57bl6/J mice & $\begin{array}{l}\text { C57bl6/J mice-fed high-fat diet } \\
\text { with or without the prebiotic } \\
\text { oligofructose or cellulose, } \\
\text { microbiota enumerated by FISH }\end{array}$ & $\begin{array}{l}\text { Prebiotic supplementation of high- } \\
\text { fat diet stimulates bifidobacterial } \\
\text { numbers, reduces metabolic } \\
\text { endotoxemia and metabolic } \\
\text { disease. Bifidobacterial numbers } \\
\text { were inversely proportional to } \\
\text { plasma LPS }\end{array}$ & $\begin{array}{l}\text { Prebiotics may reduce intestinal } \\
\text { permeability and reduce } \\
\text { metabolic endotoxemia via } \\
\text { reduced plasma LPS }\end{array}$ & $\begin{array}{c}\text { Cani et al. } \\
(2007 \mathrm{c})\end{array}$ \\
\hline Human adults & $\begin{array}{l}\text { Fecal bacterial composition of } \\
\text { obese }(n=16) \text { on different diets; } \\
\text { maintenance, high-protein- } \\
\text { medium carbohydrate, high } \\
\text { protein/low carbohydrate. } \\
\text { Microbiota enumerated by FISH }\end{array}$ & $\begin{array}{l}\text { Roseburia spp. and Eubacteium } \\
\text { rectale subgroup, and } \\
\text { bifidobacteria decrease with the } \\
\text { high-protein/low-carbohydrate } \\
\text { diet, accompanied by a decrease } \\
\text { in fecal butyrate }\end{array}$ & $\begin{array}{l}\text { Gut microbiota and fecal butyrate } \\
\text { concentrations change in relation } \\
\text { to the presence of dietary } \\
\text { fermentable carbohydrate }\end{array}$ & $\begin{array}{l}\text { Duncan et al. } \\
\text { (2007) }\end{array}$ \\
\hline $\begin{array}{l}\mathrm{C} 57 \mathrm{bl6} / \mathrm{J} o b / o b \\
\text { mice }\end{array}$ & $\begin{array}{l}\text { Cecal microbiota of mice under } \\
\text { high-fat low-fiber diet, and } \\
\text { antibiotics. Microbiota } \\
\text { enumerated by qPCR and DGGE }\end{array}$ & $\begin{array}{l}\text { Antibiotic reduced LPS cecal } \\
\text { content in } o b / o b \text { and high fat } \\
\text { High-fat diet increased intestinal } \\
\text { permeability and LPS uptake } \\
\text { leading to metabolic endotoxemia }\end{array}$ & $\begin{array}{l}\text { Obese/high-fat modified microbiota } \\
\text { contributes to increased gut wall } \\
\text { permeability and metabolic } \\
\text { endotoxemia, which can be } \\
\text { reversed by antibiotics }\end{array}$ & $\begin{array}{l}\text { Cani et al. } \\
\text { (2008) }\end{array}$ \\
\hline $\begin{array}{l}\text { Human } \\
\text { pregnant }\end{array}$ & $\begin{array}{l}\text { Comparison of the fecal microbiota } \\
\text { (flow cytometry FISH, and qPCR) } \\
\text { of overweight }(n=18) \text { and } \\
\text { normo-weight }(n=36) \text { during } \\
\text { first and third trimesters }\end{array}$ & $\begin{array}{l}\text { Bacteroides and Staphylococcus } \\
\text { aureus were counted in higher } \\
\text { numbers in overweight compared } \\
\text { with normo-weight pregnant } \\
\text { women }\end{array}$ & $\begin{array}{l}\text { Overweight can lead to aberrant gut } \\
\text { microbiota during pregnancy } \\
\text { inclining toward aberrant gut } \\
\text { microbiota development in the } \\
\text { infant and promoting subsequent } \\
\text { obesity }\end{array}$ & $\begin{array}{l}\text { Collado et al. } \\
\text { (2008) }\end{array}$ \\
\hline
\end{tabular}


Table 1 continued

\begin{tabular}{|c|c|c|c|c|}
\hline Model & Design & Evidence & Proposed mechanism & References \\
\hline Human adults & $\begin{array}{l}\text { Fecal microbiota difference } \\
\text { (measured by FISH), between } \\
\text { lean and obese, and obese upon } \\
\text { weight loss }\end{array}$ & $\begin{array}{l}\text { No difference in Bacteroides } \\
\text { populations between lean or } \\
\text { obese, or upon weight loss in } \\
\text { obese. Diet-correlated decrease in } \\
\text { Firmicutes (Roseburia, } \\
\text { E. rectale), and bifidobacteria in } \\
\text { obese on weight loss }\end{array}$ & $\begin{array}{l}\text { Diets conceived for weight loss } \\
\text { purpose of obese subject change } \\
\text { the composition of gut-hosted } \\
\text { microbiota }\end{array}$ & $\begin{array}{l}\text { Duncan et al. } \\
\text { (2008) }\end{array}$ \\
\hline $\begin{array}{l}\text { Human } \\
\text { children }\end{array}$ & $\begin{array}{l}\text { Retrospective study of fecal } \\
\text { microbiota profile (FISH, flow } \\
\text { cytometry, and qPCR) of infants } \\
\text { presenting with either obesity or } \\
\text { normal weight at age } 7 \text { years ( } 25 \\
\text { out of 49) }\end{array}$ & $\begin{array}{l}\text { The obese children showed at } \\
\text { infancy a fecal microbiota lower } \\
\text { in bifidobacteria but higher in } \\
\text { Staphylococcus aureus compared } \\
\text { with infant who remained lean at } \\
7 \text { years }\end{array}$ & $\begin{array}{l}\text { Aberrant gut microbiota } \\
\text { development during infancy } \\
\text { contributes to obesity risk at } \\
\text { childhood }\end{array}$ & $\begin{array}{l}\text { Kalliomaki } \\
\text { et al. (2008) }\end{array}$ \\
\hline $\begin{array}{l}\text { Male Sprague- } \\
\text { Dawley rats }\end{array}$ & $\begin{array}{l}\text { Induction of excess of body weight } \\
\text { in pups in over-nutrition and } \\
\text { normal nutrition condition with } \\
\text { microbiota enumerated by FISH } \\
\text { and plate count }\end{array}$ & $\begin{array}{l}\text { Obesity resulted from overfed small } \\
\text { litters who had reduced } \\
\text { Bacteroides and increased } \\
\text { enterococci and lactobacilli } \\
\text { compared with normo-weight, } \\
\text { conventionally housed and fed } \\
\text { animals }\end{array}$ & $\begin{array}{l}\text { Postnatal nutrition has obesity- } \\
\text { inducing potential by impacting } \\
\text { the gut microbiota development }\end{array}$ & $\begin{array}{l}\text { Mozes et al. } \\
\text { (2008) }\end{array}$ \\
\hline $\begin{array}{l}\text { Germ-free } \\
\text { C57BL/6 J } \\
\text { mice }\end{array}$ & $\begin{array}{l}\text { Conventional under Western-style } \\
\text { or high-carbohydrate diets and } \\
\text { conventionalized with obese-type } \\
\text { microbiota from Western-style or } \\
\text { high-carbohydrate diets. The } \\
\text { colon microbiota was examined } \\
\text { by PCR-based 16S rRNA gene } \\
\text { fragment sequencing and } \\
\text { functional analysis }\end{array}$ & $\begin{array}{l}\text { Western-style diet and associated } \\
\text { obesity induced Firmicutes bloom } \\
\text { characterized by increased } \\
\text { abundance of in a single } \\
\text { phylogenetic clade within the } \\
\text { Mollicutes class; relative } \\
\text { abundance of Bacteroidetes } \\
\text { decreased. Conventionalization of } \\
\text { lean germ-free mice with } \\
\text { Mollicutes-dominated microbiota } \\
\text { lead to higher body weight gain } \\
\text { than with lean-type microbiota. } \\
\text { Western diet/Mollicutes- } \\
\text { modulated microbiota have a } \\
\text { higher capacity for intake and } \\
\text { fermentation of simple sugars }\end{array}$ & $\begin{array}{l}\text { Western-style diet selects for a } \\
\text { particular gut microbiota with } \\
\text { increased capacity for energy } \\
\text { recovery from diet }\end{array}$ & $\begin{array}{l}\text { Turnbaugh } \\
\text { et al. (2008) }\end{array}$ \\
\hline Human adults & $\begin{array}{l}\text { qPCR analysis of the gut microbiota } \\
\text { of obese, anorexic, and lean } \\
\text { human adults }\end{array}$ & $\begin{array}{l}\text { Lower Bacterioidetes in obese } \\
\text { patients and obese microbiota } \\
\text { enriched in Lactobacillus }\end{array}$ & $\begin{array}{l}\text { Gut microbiota displays distinct } \\
\text { pattern in obesity }\end{array}$ & $\begin{array}{l}\text { Armougom } \\
\text { et al. (2009) }\end{array}$ \\
\hline Mice & $\begin{array}{l}\text { Wild-type and RELM } \beta \text { KO mice } \\
\text { from a normal to a high-fat diet. } \\
\text { Microbial evaluation by } 16 \mathrm{~S} \\
\text { rDNA deep sequencing using } 454\end{array}$ & $\begin{array}{l}\text { Gut microbiota from normal diet } \\
\text { (Bacterioidetes more abundant } \\
\text { than Firmicutes, mostly Clostridia } \\
\text { genus with lower abundance of } \\
\text { Tenericutes, Proteobacteria) } \\
\text { shifted after high-fat diet to higher } \\
\text { proportion of Firmicutes (mostly } \\
\text { Clostridiales) and lower } \\
\text { Bacteriodetes (Bacteriodacee, } \\
\text { Prevotellaceae, Rickenellaceae, } \\
\text { the more affected orders) together } \\
\text { with a bloom of Proteobacteria } \\
\text { (Desulfuvibrionaceae) } \\
\text { Change also in amino acid and } \\
\text { carbohydrate metabolism, which } \\
\text { were less abundant after high-fat } \\
\text { feeding }\end{array}$ & $\begin{array}{l}\text { Impact of dietary fat on the gut } \\
\text { microbiota composition and } \\
\text { metabolism: changes induced by } \\
\text { obesity or direct from fat }\end{array}$ & $\begin{array}{l}\text { Hildebrandt } \\
\text { et al. (2009) }\end{array}$ \\
\hline
\end{tabular}


Table 1 continued

\begin{tabular}{|c|c|c|c|c|}
\hline Model & Design & Evidence & Proposed mechanism & References \\
\hline $\begin{array}{l}\text { Human } \\
\text { adolescents }\end{array}$ & $\begin{array}{l}\text { Fecal microbiota (FISH and IgA- } \\
\text { coating bacteria) of obese } \\
\text { adolescents before and after } \\
\text { restricted calorie diet and physical } \\
\text { activity regime ( } n=39, \\
10 \text { weeks) }\end{array}$ & $\begin{array}{l}\text { C. histolyticum, E. rectale-C. } \\
\text { coccoides groups decreased count } \\
\text { with weight loss; Bacteroides- } \\
\text { Prevotella increased upon weight } \\
\text { loss of }>4 \mathrm{~kg} \text {; } \\
\text { IgA-coating bacteria decreased in } \\
\text { those who lost }>6 \mathrm{~kg}\end{array}$ & $\begin{array}{l}\text { Potential link between diet, gut } \\
\text { microbiota, immunity, and host } \\
\text { metabolic processes involved in } \\
\text { obesity }\end{array}$ & $\begin{array}{l}\text { Nadal et al. } \\
\text { (2009) }\end{array}$ \\
\hline $\begin{array}{l}\text { Human } \\
\text { adolescents }\end{array}$ & $\begin{array}{l}\text { Fecal microbiota (qPCR) of } \\
\text { overweight adolescents }(n=36) \\
\text { under calorie-restricted diet and } \\
\text { physical activity }\end{array}$ & $\begin{array}{l}\text { Total bacterial were higher, as were } \\
\text { Bacterioides fragilis and } \\
\text { Clostridium leptum and } \\
\text { Bifidobacterium catenulatum in } \\
\text { the obese population in which } \\
\text { intervention was more effective. } \\
\text { C. coccoides, Lactobacillus, } \\
\text { Bifidobacterium, B. bifidus, and } \\
\text { B. breve were lower. The weight } \\
\text { loss dietary intervention affected } \\
\text { also B. longum }\end{array}$ & $\begin{array}{l}\text { Differences in the gut microbiota } \\
\text { are correlated with a high } \\
\text { effective response to weight loss } \\
\text { inducing intervention }\end{array}$ & $\begin{array}{l}\text { Santacruz } \\
\text { et al. (2009) }\end{array}$ \\
\hline Humans adults & $\begin{array}{l}\text { Intestinal microbiota (qPCR) and } \\
\text { feces SCFA of lean }(n=30), \\
\text { overweight }(n=35), \text { and obese } \\
(n=33) \text { humans }\end{array}$ & $\begin{array}{l}\text { Higher proportion of Bacterioidetes } \\
\text { in overweight and obese. } \\
\text { Ruminococcus flavefaciens } \\
\text { subgroup reduced in overweight } \\
\text { and obese Clostridium leptum } \\
\text { group, Methanobrevibacter and } \\
\text { Bifidobacterium all reduced in } \\
\text { overweight and obese } \\
\text { Higher amount of SCFA in obese, } \\
\text { more propionate in overweight } \\
\text { and obese }\end{array}$ & $\begin{array}{l}\text { SCFA concentration elevated in } \\
\text { obese feces with significant } \\
\text { differences in the composition of } \\
\text { gut microbiota between lean and } \\
\text { obese at phylum and sub-phylum } \\
\text { levels }\end{array}$ & $\begin{array}{l}\text { Schwiertz } \\
\text { et al. (2010) }\end{array}$ \\
\hline $\begin{array}{l}\text { Human female } \\
\text { twins and } \\
\text { their mothers }\end{array}$ & $\begin{array}{l}\text { Adult female monozygotic and } \\
\text { dizygotic twin pairs concordant } \\
\text { for obesity and their mothers } \\
\text { ( } n=31,23 \text { and } 46 \text {, respectively) } \\
\text { Gut microbiota described by } 16 \text { s } \\
\text { rRNA gene sequencing }\end{array}$ & $\begin{array}{l}\text { Lower abundance of Bacteroidetes, } \\
\text { but higher Actinobacteria (no } \\
\text { change in Firmicutes) in obese. } \\
\text { Reduced species diversity in } \\
\text { obese. Metabolic pathways and } \\
\text { functional genes altered in } \\
\text { obesity. Functional heterogeneity } \\
\text { associated with the relative } \\
\text { amount of Bacteroidetes. } \\
\text { Microbiota enriched in } \\
\text { Firmicutes/Actinobacteria } \\
\text { exhibited more less diverse } \\
\text { functions }\end{array}$ & $\begin{array}{l}\text { Modulated functional microbiome } \\
\text { with metagenomic differences in } \\
\text { carbohydrate, lipid, and amino } \\
\text { acid metabolism }\end{array}$ & $\begin{array}{l}\text { Turnbaugh } \\
\text { et al. } \\
\text { (2009a) }\end{array}$ \\
\hline $\begin{array}{l}\text { Zucker } f a / f a, \\
\text { fa/ }+ \text { and }+/ \\
+ \text { rats }\end{array}$ & $\begin{array}{l}\text { Cecal microbiota composition } \\
\text { (FISH and DGGE) in Zucker } \\
\text { genotypes on normal diet } \\
\text { correlated with }{ }^{1} \mathrm{H}-\mathrm{NMR} \\
\text { metabolomics of urine and blood }\end{array}$ & $\begin{array}{l}\text { Microbiota of obese } f a / f a \text { animals } \\
\text { distinct from non-obese } \\
\text { genotypes. Total bacteria, } \\
\text { bifidobacteria, lactobacilli, and } \\
\text { Atopobium species, all } \\
\text { significantly lower in obese ceca. } \\
\text { Distinct urine and plasma } \\
\text { metabolite profiles associated } \\
\text { with obesity and obese-type } \\
\text { microbiota }\end{array}$ & $\begin{array}{l}\text { Gut microbiota of the Zucker } \\
\text { genetic model of obesity linked to } \\
\text { energy metabolism and obesity in } \\
\text { these animals }\end{array}$ & $\begin{array}{l}\text { Waldram } \\
\text { et al. (2009) }\end{array}$ \\
\hline $\begin{array}{l}\text { Humans post- } \\
\text { gastric } \\
\text { bypass } \\
\text { (PGB) } \\
\text { surgery }\end{array}$ & $\begin{array}{l}\text { Fecal microbiota from } 3 \text { lean, } 3 \\
\text { morbidly obese, and } 3 \text { PGB } \\
\text { surgery patients upon weight loss } \\
\text { describe after PCR-based } 16 \mathrm{~S} \\
\text { rRNA gene fragment sequencing } \\
\text { and qPCR for methanogens }\end{array}$ & $\begin{array}{l}\text { Bacterioidetes (Prevotellaceae) } \\
\text { more abundant in obese } \\
\text { Firmicutes dominant in lean and } \\
\text { obese but reduced in PGB, PGB } \\
\text { had increased } \\
\text { Gammaproteobacteria } \\
\text { Methanogenic functional group } \\
\text { elevated in obese }\end{array}$ & $\begin{array}{l}\text { Increased methanogenesis, } \\
\text { enhancing fermentation through } \\
\text { relief of end-product inhibition } \\
\text { increases production of acetate } \\
\text { absorbed at the human gut } \\
\text { contributing to enhanced energy } \\
\text { recovery }\end{array}$ & $\begin{array}{l}\text { Zhang et al. } \\
\text { (2009) }\end{array}$ \\
\hline
\end{tabular}


Table 1 continued

\begin{tabular}{|c|c|c|c|c|}
\hline Model & Design & Evidence & Proposed mechanism & References \\
\hline $\begin{array}{l}\text { Human } \\
\text { children }\end{array}$ & $\begin{array}{l}\text { Obese and non-obese Indian } \\
\text { children (11-14 years: } n: 28) \\
\text { fecal microbiota enumerated by } \\
\text { 16S rRNA target by qPCR }\end{array}$ & $\begin{array}{l}\text { Bacterioides-Prevotella, } \\
\text { Lactobacillus acidophilus, } \\
\text { Eubacterium rectale were not } \\
\text { significantly different in obese } \\
\text { and non-obese. High number of } \\
\text { Faecalibacterium prausnitzii } \\
\text { characterized the obese children }\end{array}$ & $\begin{array}{l}\text { Evident alteration of gut microbiota } \\
\text { in obese children }\end{array}$ & $\begin{array}{l}\text { Balamurugan } \\
\text { et al. (2010) }\end{array}$ \\
\hline $\begin{array}{l}\text { Sprague- } \\
\text { Dawley rat }\end{array}$ & $\begin{array}{l}\text { Obesity-prone (DIO-P) and } \\
\text { resistant (DIO-R) rats under high- } \\
\text { fat diet were examined for } 16 \mathrm{~S} \\
\text { rRNA qPCR microbiota, TLR4, } \\
\text { and LPS }\end{array}$ & $\begin{array}{l}\text { Reduced total bacterial count with } \\
\text { higher relative proportions of } \\
\text { Bacterioidales and Clostridiales } \\
\text { after high-fat feeding. Greater } \\
\text { abundance of Enterobacteriales in } \\
\text { DIO-P } \\
\text { Increased intestinal permeability } \\
\text { and plasma LPS upon high-fat } \\
\text { feeding }\end{array}$ & $\begin{array}{l}\text { Change in microbiota induced by } \\
\text { high-fat diet and inflammation } \\
\text { development associated with } \\
\text { obesity }\end{array}$ & $\begin{array}{l}\text { de La Serre } \\
\text { et al. (2010) }\end{array}$ \\
\hline $\begin{array}{l}\text { Germ-free } \\
(\mathrm{GF}) \text { and } \\
\text { conventional } \\
(\mathrm{CV}) \text { mice }\end{array}$ & $\begin{array}{l}\text { Fecal microbiota and Fiaf/Angptl4 } \\
\text { in GF and CV male adult mice on } \\
\text { low-fat diet (LFD), a high-fat diet } \\
\text { (HFD), or a commercial Western } \\
\text { diet (WD) }\end{array}$ & $\begin{array}{l}\text { Bacteroidetes relative amount was } \\
\text { lower in on both HFD and WD in } \\
\text { favor of Firmicutes. One species } \\
\text { of Firmicutes was predominated: } \\
\text { the Erysipelotrichaceae } \\
\text { Higher expression of Fiaf/Angptl4 } \\
\text { at intestinal level in HFD and WD }\end{array}$ & $\begin{array}{l}\text { Concluded that the absence of gut } \\
\text { microbiota does not provide a } \\
\text { general protection from diet- } \\
\text { induced obesity, that intestinal } \\
\text { production of intestinal Fiaf/ } \\
\text { Angptl4 and gut microbiota are } \\
\text { not linked together in fat storage. } \\
\text { Diet composition highly affects } \\
\text { gut microbiota }\end{array}$ & $\begin{array}{l}\text { Fleissner } \\
\text { et al. (2010) }\end{array}$ \\
\hline $\begin{array}{l}\text { C57bl6/J ob/ob } \\
\text { mice }\end{array}$ & $\begin{array}{l}\text { Feces of } o b / o b \text { (low-fat diet) } \\
\text { compared to wild type (low-fat } \\
\text { and high-fat diet HF) for their } \\
\text { metagenomic profile ( } 16 \mathrm{~S} \text { rRNA } \\
\text { tags pyrosequencing) in relation } \\
\text { to low-fat and high-fat diet. SCFA } \\
\text { analysis }\end{array}$ & $\begin{array}{l}\text { Firmicutes more abundant in ob/ob } \\
\text { and HF wild mice. Bacteriodes } \\
\text { significantly decrease in ob/ob. } \\
\text { Actinobacteria increased in ob/ob } \\
\text { and HF mice from } 7 \text { to } 11 \text { weeks. } \\
\text { Protobacteria decline in HF mice. } \\
\text { Bifidobacteria decline in } o b / o b \\
\text { and HF at } 11 \text { weeks } \\
\text { SCFA concentrations and fecal } \\
\text { energy content higher in obese at } \\
\text { week } 7 \text { but lower upon adaptation } \\
\text { to diet }\end{array}$ & $\begin{array}{l}\text { High-fat diet may have more } \\
\text { influence gut microbiota } \\
\text { composition than host genotype. } \\
\text { Diet and obesity-induced changes } \\
\text { in microbiota energy harvesting } \\
\text { change upon adaptation to high- } \\
\text { fat diet }\end{array}$ & $\begin{array}{l}\text { Murphy et al. } \\
\text { (2010) }\end{array}$ \\
\hline $\begin{array}{l}\text { Human } \\
\text { pregnant }\end{array}$ & $\begin{array}{l}\text { Feces from overweight ( } n \text { 16) and } \\
\text { normal weight }(n \text { 34) pregnant } \\
\text { women analyzed by qPCR, } \\
\text { together with monitoring of body } \\
\text { weight and biochemical } \\
\text { parameters from plasma }\end{array}$ & $\begin{array}{l}\text { Overweight women had more } \\
\text { abundant fecal Enterobacteriacee, } \\
\text { E. coli, and Staphylococcus and } \\
\text { lower counts of Bifidobacterium } \\
\text { and Bacterioidetes in comparison } \\
\text { with normal weight subjects. A. } \\
\text { muciniphila and Bifidobacterium } \\
\text { were higher in subjects with } \\
\text { normal weight gain, compared } \\
\text { with those with excessive weight } \\
\text { gain. C. leptum and } \\
\text { Staphylococcus counts correlated } \\
\text { with excessive weight gain. } \\
\text { Higher amount of folic acid and } \\
\text { Fe in normal weight subject }\end{array}$ & $\begin{array}{l}\text { Gut microbiota associated with } \\
\text { body weight and body weight } \\
\text { gain, pregnancy important } \\
\text { metabolites, beneficial health } \\
\text { effect on woman and infant }\end{array}$ & $\begin{array}{l}\text { Santacruz } \\
\text { et al. (2010) }\end{array}$ \\
\hline Mice & $\begin{array}{l}\text { Wild-type and Apoa-I knocked out } \\
\text { mice intolerant to glucose, under } \\
\text { fat or normal diet, DGGE-DNA } \\
\text { fingerprint and } 16 \mathrm{~S} \text { rRNA } \\
\text { pyrosequencing }\end{array}$ & $\begin{array}{l}\text { Bifidobacteriacea disappeared after } \\
\text { high-fat diet and } \\
\text { Desulfovibrionacea prevailed in } \\
\text { the glucose impaired/obese group }\end{array}$ & $\begin{array}{l}\text { High impact of diet on the } \\
\text { microbiota composition, } \\
\text { potentially capable to induce } \\
\text { metabolic syndrome }\end{array}$ & $\begin{array}{l}\text { Zhang et al. } \\
\text { (2010) }\end{array}$ \\
\hline
\end{tabular}


whereas low body weight, preterm infants are more likely to have higher body weight in later life.

However, the discussed mechanisms and their involvement with the gut microbiota and obesity axis have to be further explored, in particular to establish the role of colonic fermentation in human energy homeostasis. The combination of the metagenomic and metabolomic approaches appears to offer a very powerful tool for the elucidation of underlying metabolic interactions between the gut microbiota and its host and ultimately to elucidate the cause or effect relationship between the aberrant gut microbiota in obesity and the diseases of obesity.

\section{References}

Agheli N, Kabir M, Berni-Canani S, Petitjean E, Boussairi A, Luo J, Bornet F, Slama G, Rizkalla SW (1998) Plasma lipids and fatty acid synthase activity are regulated by short-chain fructooligosaccharides in sucrose-fed insulin-resistant rats. J Nutr 128(8):1283-1288

Amar J, Burcelin R, Ruidavets JB, Cani PD, Fauvel J, Alessi MC, Chamontin B, Ferrieres J (2008) Energy intake is associated with endotoxemia in apparently healthy men. Am $\mathrm{J}$ Clin Nut 87(5):1219-1223

Anderson RC, Cookson AL, McNabb WC, Kelly WJ, Roy NC (2010) Lactobacillus plantarum DSM 2648 is a potential probiotic that enhances intestinal barrier function. FEMS Microbiol Lett 309:184-192. doi:10.1111/j.1574-6968.2010.02038.x

Armougom F, Henry M, Vialettes B, Raccah D, Raoult D (2009) Monitoring bacterial community of human gut microbiota reveals an increase in Lactobacillus in obese patients and methanogens in anorexic patients. PLOS ONE 4(9):art. no. e7125

Ayyad C, Andersen T (2000) Long-term efficacy of dietary treatment of obesity: a systematic review of studies published between 1931 and 1999. Obes Rev 1(2):113-119. doi:10.1046/j.1467789x.2000.00019.x

Bäckhed F (2010) Addressing the gut microbiome and implications for obesity. Int Dairy J 20(4): 259-261. Sp. Iss. SI. doi: 10.1016/j.idairyj.2009.11.012

Bäckhed F, Ding H, Wang T, Hooper LV, Koh GY, Nagy A, Semenkovich CF, Gordon JI (2004) The gut microbiota as an environmental factor that regulates fat storage. Proc Natl Acad Sci USA 101(44):15718-15723. doi:10.1073/pnas.0407076101

Bäckhed F, Manchester JK, Semenkovich CF, Gordon JI (2007) Mechanisms underlying the resistance to diet-induced obesity in germ-free mice. Proc Natl Acad Sci USA 104(3):979-984. doi: 10.1073/pnas.0605374104

Balamurugan R, George G, Kabeerdoss J, Hepsiba J, Chandragunasekaran AMS, Ramakrishna BS (2010) Quantitative differences in intestinal Faecalibacterium prausnitzii in obese Indian children. Br J Nutr 103(3):335-338. doi:10.1017/S000711450 9992182

Baldini M, Pasqui F, Bordoni A, Maranesi M (2009) Is the Mediterranean lifestyle still a reality? Evaluation of food consumption and energy expenditure in Italian and Spanish university students. Public Health Nutr 12(2):148-155 [Epub 2008 May 27]

Barbara G (2006) Mucosal barrier defects in irritable bowel syndrome. Who left the door open? Am J Gastroenterol 101(6):1295-1298. doi:10.1111/j.1572-0241.2006.00667.x
Bates JM, Mittge E, Kuhlman J, Baden KN, Cheesman SE, Guillemin K (2006) Distinct signals from the microbiota promote different aspects of zebrafish gut differentiation. Dev Biol 297(2): 374-386. doi:10.1016/j.ydbio.2006.05.006

Brighenti F (2007) Dietary fructans and serum triacylglycerols: a metaanalysis of randomized controlled trials. J Nutr 137(11 Suppl): 2552S-2556S

Brinkworth GD, Noakes M, Clifton PM, Bird AR (2009) Comparative effects of very low-carbohydrate, high-fat and high-carbohydrate, low-fat weight-loss diets on bowel habit and faecal short-chain fatty acids and bacterial populations. Br $\mathrm{J}$ Nutr 101(10):1493-1502. doi:10.1017/S0007114508094658

Cani PD, Amar J, Iglesias MA, Poggi M, Knauf C, Bastelica D, Neyrinck AM, Fava F, Tuohy KM, Chabo C, Waget A, Delmee E, Cousin B, Sulpice T, Chamontin B, Ferrieres J, Tanti JF, Gibson GR, Casteilla L, Delzenne NM, Alessi MC, Burcelin R (2007a) Metabolic endotoxemia initiates obesity and insulin resistance. Diabetes 56(7):1761-1772. doi:10.2337/db06-1491

Cani PD, Hoste S, Guiot Y, Delzenne NM (2007b) Dietary nondigestible carbohydrates promote L-cell differentiation in the proximal colon of rats. Br J Nutr 98(1):32-37. doi:10.1017/ S0007114507691648

Cani PD, Neyrinck AM, Fava F, Knauf C, Burcelin RG, Tuohy KM, Gibson GR, Delzenne NM (2007c) Selective increases of bifidobacteria in gut microflora improve high-fat-diet-induced diabetes in mice through a mechanism associated with endotoxaemia. Diabetologia 50(11):2374-2383. doi:10.1007/s00125007-0791-0

Cani PD, Bibiloni R, Knauf C, Neyrinck AM, Neyrinck AM, Delzenne NM, Burcelin R (2008) Changes in gut microbiota control metabolic endotoxemia-induced inflammation in high-fat diet-induced obesity and diabetes in mice. Diabetes 57(6):1470 1481. doi:10.2337/db07-1403

Cani PD, Possemiers S, Van de Wiele T, Guiot Y, Everard A, Rottier O, Geurts L, Naslain D, Neyrinck A, Lambert DM, Muccioli GG, Delzenne NM (2009) Changes in gut microbiota control inflammation in obese mice through a mechanism involving GLP-2-driven improvement of gut permeability. Gut 58(8): 1091-1103. doi:10.1136/gut.2008.165886

Celi F, Bini V, De Giorgi G, Molinari D, Faraoni F, Di Stefano G, Bacosi ML, Berioli MG, Contessa G, Falorni A (2003) Epidemiology of overweight and obesity among school children and adolescents in three provinces of central Italy, 1993-2001: study of potential influencing variables. Eur J Clin Nutr 57(9):1045-1051. doi:10.1038/sj.ejcn.1601640

Chen KT, Malo MS, Beasley-Topliffe LK, Poelstra K, Millan JL, Mostafa G, Alam SN, Ramasamy S, Warren HS, Hohmann EL, Hodin RA (2011) A role for intestinal alkaline phosphatase in the maintenance of local gut immunity. Dig Dis Sci 56:1020-1027. doi:10.1007/s10620-010-1396-x

Cherbut C, Ferrier L, Rozé C et al (1998) Short-chain fatty acids modify colonic motility through nerves and polypeptide YY release in the rat. Am J Physiol 275:G1415-G1422

Collado MC, Isolauri E, Laitinen K, Salminen S (2008) Distinct composition of gut microbiota during pregnancy in overweight and normal-weight women. Am J Clin Nut 88:894-899

Cuche G, Cuber JC, Malbert CH (2000) Ileal short-chain fatty acids inhibit gastric motility by a humoral pathway. Am J Physiol Gastrointest Liver Physiol 279:G925-G930

Cummings JH, Antoine JM, Azpiroz F, Bourdet-Sicard R, Brandtzaeg P, Calder PC, Gibson GR, Guarner F, Isolauri E, Pannemans D, Shortt C, Tuijtelaars S, Watzl B (2004) PASSCLAIM-gut health and immunity. Eur J Nutr 43(Suppl 2):II118-II173. doi: 10.1007/s00394-004-1205-4

Dankert J, Zijlstra J, Wolthers B (1981) Volatile fatty acids in human peripheral and portal blood: quantitative determination, vacuum 
distillation, and gas chromatography. Clin Chim Acta 110:301-307. doi:10.1016/0009-8981(81)90359-4

Darzi J, Frost GS, Robertson MD (2011) Do SCFA have a role in appetite regulation? Proc Nutr Soc 70:119-128. doi:10.1017/ S0029665110004039

Daubioul C, Rousseau N, Demeure R, Gallez B, Taper H, Declerck B, Delzenne N (2002) Dietary fructans, but not cellulose, decrease triglyceride accumulation in the liver of obese Zucker fa/fa rats. J Nutr 132:967-973

De Filippo C, Cavalieri D, Di Paola M, Ramazzotti M, Poullet JB, Massart S, Collini S, Pieraccini G, Lionetti P (2010) Impact off diet in shaping gut microbiota revealed by a comparative study in children from Europe and rural Africa. Proc Natl Acad Sci USA 17:14691-14696. doi:10.1073/pnas.1005963107

de La Serre CB, Ellis CL, Lee J, Hartman AL, Rutledge JC, Raybould HE (2010) Propensity to high-fat diet-induced obesity in rats is associated with changes in the gut microbiota and gut inflammation. Am J Physiol Gastrointest Liver Physiol 299:G440 G448. doi:10.1152/ajpgi.00098.2010

di Giuseppe R, Bonanni A, Olivieri M, Di Castelnuovo A, Donati MB, de Gaetano G, Cerletti C, Iacoviello L (2008) Adherence to Mediterranean diet and anthropometric and metabolic parameters in an observational study in the 'Alto Molise' region: the MOLI-SAL project. Nutr Metab Cardiovasc Dis 18:415-421. doi:10.1016/j.numecd.2007.05.010

Drucker DJ (1999) Glucagon-like peptide 2. Trends Endocrinol Metab 10:153-156. doi:10.1016/S1043-2760(98)00136-2

Dumas ME, Barton RH, Toye A, Cloarec O, Blancher C, Rothwell A, Fearnside J, Tatoud R, Blanc V, Lindon JC, Mitchell SC, Holmes E, McCarthy MI, Scott J, Gauguier D, Nicholson JK (2006) Metabolic profiling reveals a contribution of gut microbiota to fatty liver phenotype in insulin-resistant mice. Proc Natl Acad Sci USA 103:12511-12516. doi:10.1073/pnas.0601056103

Duncan SH, Belenguer A, Holtrop G, Johnstone AM, Flint HJ, Lobley GE (2007) Reduced dietary intake of carbohydrates by obese subjects results in decreased concentrations of butyrate and butyrate-producing bacteria in feces. Appl Environ Microbiol 73:1073-1078. doi:10.1128/AEM.02340-06

Duncan SH, Lobley GE, Holtrop G, Ince J, Johnstone AM, Louis P, Flint HJ (2008) Human colonic microbiota associated with diet, obesity and weight loss. Int J Obes 32:1720-1724. doi:10.1038/ ijo. 2008.155

Fava F, Lovegrove JA, Gitau R, Jackson KG, Tuohy KM (2006) The gut microbiota and lipid metabolism: Implications for human health and coronary heart disease. Curr Med Chem 13:30053021. doi:10.1021/jf101475m

Favier ML, Moundras C, Demigné C, Rémésy C (1995) Fermentable carbohydrates exert a more potent cholesterol-lowering effect than cholestyramine. Biochim Biophys Acta 14;1258(2):115121

Fleissner CK, Huebel N, El-Bary MMA, Loh G, Klaus S, Blaut M (2010) Absence of intestinal microbiota does not protect mice from diet-induced obesity. Br J Nutr 104:919-929. doi: 10.1017/S0007114510001303

Fukasawa T, Kamei A, Watanabe Y, Koga J, Abe K (2010) Shortchain fructooligosaccharide regulates hepatic peroxisome proliferator-activated receptor alpha and farnesoid $\times$ receptor target gene expression in rats. J Agric Food Chem 58:7007-7012. doi: 10.1021/jf1006616

Gao ZG, Yin J, Zhang J, Ward RE, Martin RJ, Lefevre M, Cefalu WT, Ye JP (2009) Butyrate improves insulin sensitivity and increases energy expenditure in mice. Diabetes 58:1509-1517. doi: $10.2337 / \mathrm{db} 08-1637$

Ghoshal S, Witta J, Zhong J, de Villiers W, Eckhardt E (2009) Chylomicrons promote intestinal absorption of lipopolysaccharides. J Lipid Res 50:90-97. doi:10.1194/j1r.M800156-JLR200
Guttman JA, Samji FN, Li Y, Vogl AW, Finlay BB (2006) Evidence that tight junctions are disrupted due to intimate bacterial contact and not inflammation during attaching and effacing pathogen infection in vivo. Infect Immun 74:6075-6084. doi:10.1128/ IAI.00721-06

Hildebrandt MA, Hoffmann C, Hamady M, Chen YY, Knight R, Bushman FD, Ahima RS, Wu GD (2009) High fat diet determines the composition of the gut microbiome independent of host genotype and phenotype. Gastroenterology 136:A102A102, Suppl. 1

Hooper LV, Wong MH, Thelin A, Hansson L, Falk PG, Gordon JI (2001) Molecular analysis of commensal host-microbial relationships in the intestine. Science 291(5505):881-884. doi: 10.1126/science.291.5505.881

Hotamisligil GS, Erbay E (2008) Nutrient sensing and inflammation in metabolic diseases. Nat Rev Immunol 8:923-934. doi: 10.1038/nri2449

Hotamisligil GS, Peraldi P, Budavari A, Ellis R, White MF, Spiegelman BM (1996) IRS-1-mediated inhibition of insulin receptor tyrosine kinase activity in TNF-alpha- and obesityinduced insulin resistance. Science 271(5249):665-668. doi: 10.1126/science.271.5249.665

Kadooka Y, Sato M, Imaizumi K, Ogawa A, Ikuyama K, Akai Y, Okano M, Kagoshima M, Tsuchida T (2010) Regulation of abdominal adiposity by probiotics (Lactobacillus gasseri SBT2055) in adults with obese tendencies in a randomized controlled trial. Eur J Clin Nutr 64:636-643. doi:10.1038/ ejen.2010.19

Kalliomaki M, Collado MC, Salminen S, Isolauri E (2008) Early differences in fecal microbiota composition in children may predict overweight. Am J Clin Nutr 87:534-538

Kaway T, Akira S (2006) TLR signaling. Cell Death Differ 13:816-825. doi:10.1038/sj.cdd.4401850

Keim NL, Blanton CA, Kretsch MJ (2004) America's obesity epidemic: measuring physical activity to promote an active lifestyle. J Am Diet Assoc 104:1398-1409. doi:10.1016/j.jada. 2004.06.005

Kondo T, Kishi M, Fushimi T, Kaga T (2009) Acetic acid upregulates the expression of genes for fatty acid oxidation enzymes in liver to suppress body fat accumulation. J Agric Food Chem 57:5982-5986. doi:10.1021/jf900470c

Lee HY, Park JH, Seok SH, Baek MW, Kim DJ, Lee KE, Paek KS, Lee Y, Park JH (2006) Human originated bacteria, Lactobacillus rhamnosus PL60, produce conjugated linoleic acid and show anti-obesity effects in diet-induced obese mice. Biochim Biophys Acta 1761:736-744. doi:10.1016/j.bbalip.2006.05.007

Ley RE (2010) Obesity and the human microbiome. Curr Opin Gastroenterol 26:5-11. doi:10.1097/MOG.0b013e328333d751

Ley RE, Backhed F, Turnbaugh P, Lozupone CA, Knight RD, Gordon JI (2005) Obesity alters gut microbial ecology. Proc Natl Acad Sci USA 102(31):11070-11075. doi:10.1073/pnas.0504978102

Ley RE, Turnbaugh PJ, Klein S, Gordon JI (2006) Microbial ecology - human gut microbes associated with obesity. Nature 444(7122):1022-1023. doi:10.1038/nature4441022a

Lieberman LS (2003) Dietary, evolutionary, and modernizing influences on the prevalence of type 2 diabetes. Annu Rev Nutr 23:345-377. doi:10.1146/annurev.nutr.23.011702.073212

Luoto R, Kalliomaki M, Laitinen K, Isolauri E (2010) The impact of perinatal probiotic intervention on the development of overweight and obesity: follow-up study from birth to 10 years. Int $\mathbf{J}$ Obes 34:1531-1537. doi:10.1038/ijo.2010.50

Macfarlane GT, Gibson GR (1997) Carbohydrate fermentation, energy transduction and gas metabolism in the human large intestine. In: Mackie RI, White BA (eds) Gastrointestinal microbiology, vol 1: gastrointestinal ecosystems and fermentations. Chapman and Hall, New York, pp 269-318 
Maes M (2008) The cytokine hypothesis of depression: inflammation, oxidative \& nitrosative stress (IO\&NS) and leaky gut as new targets for adjunctive treatments in depression. Neuro Endocrinol Lett 29:287-291

Maes M, Leunis JC (2008) Normalization of leaky gut in chronic fatigue syndrome (CFS) is accompanied by a clinical improvement: effects of age, duration of illness and the translocation of LPS from gram-negative bacteria. Neuro Endocrinol Lett 29:902-910

Malo MS, Biswas S, Abedrapo MA, Yeh L, Chen A, Hodin RA (2006) The pro-inflammatory cytokines, IL-1beta and TNFalpha, inhibit intestinal alkaline phosphatase gene expression. DNA Cell Biol 25:684-695

Meijer K, de Vos P, Priebe MG (2010) Butyrate and other short-chain fatty acids as modulators of immunity: what relevance for health? Curr Opin Clin Nutr Metab Care 13:715-721. doi: 10.1097/MCO.0b013e32833eebe5

Mozes S, Bujnakova D, Sefcikova Z, Kmet V (2008) Intestinal microflora and obesity in rats. Folia Microbiol 53:225-228

Murphy EF, Cotter PD, Healy S, Marques TM, O'Sullivan O, Fouhy F, Clarke SF, O'Toole PW, Quigley EM, Stanton C, Ross PR, O'Doherty RM, Shanahan F (2010) Composition and energy harvesting capacity of the gut microbiota: relationship to diet, obesity and time in mouse models. Gut 59:1635-1642. doi: 10.1136/gut.2010.215665

Nadal I, Santacruz A, Marcos A, Warnberg J, Garagorri M, Moreno LA, Martin-Matillas M, Campoy C, Marti A, Moleres A, Delgado M, Veiga OL, Garcia-Fuentes M, Redondo CG, Sanz Y (2009) Shifts in clostridia, bacteroides and immunoglobulincoating fecal bacteria associated with weight loss in obese adolescents. Int J Obes 33:758-767. doi:10.1038/ijo.2008.260

Nagao K, Inoue N, Wang YM, Shirouchi B, Yanagita T (2005) Dietary conjugated linoleic acid alleviates nonalcoholic fatty liver disease in Zucker (fa/fa) rats. J Nutr 135:9-13

Novotny R, Williams AE, Vinoya AC, Oshiro CE, Vogt TM (2009) US acculturation, food intake, and obesity among Asian-Pacific hotel workers. J Am Diet Assoc 109:1712-1718. doi:10.1016/ j.jada.2009.07.013

O’Dea K (1991) Westernisation, insulin resistance and diabetes in Australian aborigines. Med J Aust 155:258-264. doi:10.2337/ diacare.24.5.811

OECD (2010) Obesity and the economics of prevention: fit not fat. OECD Publishing. doi: 10.1787/9789264084865-en

Parnell JA, Reimer RA (2009) Weight loss during oligofructose supplementation is associated with decreased ghrelin and increased peptide YY in overweight and obese adults. Am J Clin Nut 89:1751-1759. doi:10.3945/ajcn.2009.27465

Parnell JA, Reimer RA (2010) Effect of prebiotic fibre supplementation on hepatic gene expression and serum lipids: a doseresponse study in JCR: LA-cp rats. Br J Nutr 103:1577-1584. doi:10.1017/S0007114509993539

Peters S, Pomare E, Fisher C (1992) Portal and peripheral blood shortchain fatty acid concentrations after caecal lactulose instillation at surgery. Gut 33:1249-1252. doi:10.1136/gut.33.9.1249

Pi-Sunyer X (2009) The medical risks of obesity. Postgrad Med 121:21-33. doi:10.3810/pgm.2009.11.2074

Putaala H, Salusjarvi T, Nordstrom M, Saarinen M, Ouwehand AC, Hansen EB, Rautonen N (2008) Effect of four probiotic strains and Escherichia coli $0157: \mathrm{H} 7$ on tight junction integrity and cyclo-oxygenase expression. Res Microbiol 159:692-698. doi: 10.1016/j.resmic.2008.08.002

Ravussin E, Valencia ME, Esparza J, Bennett PH, Schulz LO (1994) Effects of a traditional lifestyle on obesity in Pima Indians. Diabetes Care 17:1067-1074

Reigstad CS, Lunden GO, Felin J, Backhed F (2009) Regulation of serum amyloid A3 (SAA3) in mouse colonic epithelium and adipose tissue by the intestinal microbiota. PLos One 4:art. no. e5842. doi: 10.1371/journal.pone.0005842

Samuel BS, Gordon JI (2006) A humanized gnotobiotic mouse model of host-archaeal-bacterial mutualism. Proc Natl Acad Sci USA 103:10011-10016. doi:10.1073/pnas.0602187103

Sandek A, Rauchhaus M, Anker SD, von Haehling S (2008) The emerging role of the gut in chronic heart failure. Curr Opin Clin Nutr Metab Care 11:632-639

Santacruz A, Marcos A, Warnberg J, Marti A, Martin-Matillas M, Campoy C, Moreno LA, Veiga O, Redondo-Figuero C, Garagorri JM, Azcona C, Delgado M, Garcia-Fuentes M, Collado MC, Sanz Y (2009) EVASYON study Grp interplay between weight loss and gut microbiota composition in overweight adolescents. Obesity 17:1906-1915. doi:10.1038/oby.2009.112

Santacruz A, Collado MC, Garcia-Valdes L, Segura MT, MartinLagos JA, Anjos T, Marti-Romero M, Lopez RM, Florido J, Campoy C, Sanz Y (2010) Gut microbiota composition is associated with body weight, weight gain and biochemical parameters in pregnant women. Br J Nutr 104:83-92. doi: $10.1017 /$ S0007114510000176

Schwiertz A, Taras D, Schafer K et al (2010) Microbiota and SCFA in lean and overweight healthy subjects. Obesity 18:190-195. doi: 10.1038/oby.2009.167

So PW, Yu WS, Kuo YT, Wasserfall C, Goldstone AP, Bell JD, Frost $\mathrm{G}$ (2007) Impact of resistant starch on body fat patterning and central appetite regulation. PLoS One 2:e1309. doi:10.1371/ journal.pone.0001309

Sotos M, Nadal I, Marti A et al (2008) Gut microbes and obesity in adolescents. Proc Nutr Soc 67:E20

Spalding KL, Arner E, Westmark PO et al (2008) Dynamics of fat cell turnover in humans. Nature 453:783-787. doi:10.1038/nature 06902

Stappenbeck TS, Hooper LV, Gordon JI (2002) Developmental regulation of intestinal angiogenesis by indigenous microbes via Paneth cells. Proc Natl Acad Sci USA 99:15451-15455. doi: 10.1073/pnas.202604299

Stevenson BR, Siliciano JD, Mooseker MS, Goodenough DA (1986) Identification of ZO-1: a high molecular weight polypeptide associated with the tight junction (zonula occludens) in a variety of epithelia. J Cell Biol 103:755-766

Stoddart LA, Smith NJ, Milligan G (2008) International Union of Pharmacology. LXXI. Free fatty acid receptors FFA-1, -2, and -3 : pharmacology and pathophysiological functions. Pharmacol Rev 60:405-417. doi:10.1124/pr.108.00802

Tsukita S (2001) Claudins and the tight junction barrier. Kidney Int 60:407

Tuohy KM, Gougoulias C, Shen Q, Walton G, Fava F, Ramnani P (2009a) Studying the human gut microbiota in the trans-omics era-focus on metagenomics and metabonomics. Curr Pharm Des 15:1415-1427. doi:10.2174/138161209788168182

Tuohy KM, Costabile A, Fava F (2009b) The gut microbiota in obesity and metabolic disease-a novel therapeutic target. Nutr Ther Metab 27:113-133

Tuohy KM, Brown DT, Klinder A, Costabile A (2010) Shaping the human microbiome with prebiotic foods-current perspectives for continued development. Food Sci Tech Bull Funct Foods 7:49-64. doi:10.1616/1476-2137.15989

Turnbaugh PJ, Gordon JI (2009) The core gut microbiome, energy balance and obesity. J Physiol Lond 587:4153-4158. doi: 10.1113/jphysiol.2009.174136

Turnbaugh PJ, Ley RE, Mahowald MA, Magrini V, Mardis ER, Gordon JI (2006) An obesity-associated gut microbiome with increased capacity for energy harvest. Nature 444(7122):10271031. doi:10.1038/nature05414

Turnbaugh PJ, Baeckhed F, Fulton L, Gordon JI (2008) Diet-induced obesity is linked to marked but reversible alterations in the 
mouse distal gut microbiome. Cell Host Microbe 3:213-223. doi: 10.1016/j.chom.2008.02.015

Turnbaugh PJ, Hamady M, Yatsunenko T, Cantarel BL, Duncan A, Ley RE, Sogin ML, Jones WJ, Roe BA, Affourtit JP, Egholm M, Henrissat B, Heath AC, Knight R, Gordon JI (2009a) A core gut microbiome in obese and lean twins. Nature 457(7228):480-484. doi:10.1038/nature07540

Turnbaugh PJ, Ridaura VK, Faith JJ, Rey FE, Knight R, Gordon JI (2009b) The effect of diet on the human gut microbiome: a metagenomic analysis in humanized gnotobiotic mice. Sci Transl Med 1(6): art. no. 6ra14. doi: 10.1126/scitranslmed.3000322

Ukena SN, Singh A, Dringenberg U, Engelhardt R, Seidler U, Hansen W et al (2007) Probiotic Escherichia coli Nissle 1917 inhibits leaky gut by enhancing mucosal integrity. PLoS ONE 2:e1308. doi:10.1074/jbc.M202849200

Uribe A, Alam M, Johansson O et al (1994) Microflora modulates endocrine cells in the gastrointestinal mucosa of the rat. Gastroenterology 107:1259-1269

Vaarala O, Atkinson MA, Neu J (2008) The "perfect storm" for type 1 diabetes: the complex interplay between intestinal microbiota, gut permeability, and mucosal immunity. Diabetes 57:25552562. doi:10.2337/db08-0331

Venkatraman A, Ramakrishna BS, Pulimood AB (1999) Butyrate hastens restoration of barrier function after thermal and detergent injury to rat distal colon in vitro. Scand J Gastroenterol 34:1087-1092

Vogt JA, Ishii-Schrade KB, Pencharz PB, Wolever TMS (2004) L-Rhamnose increases serum propionate after long-term supplementation, but lactulose does not raise serum acetate. Am J Clin Nut 80:1254-1261

Waldram A, Holmes E, Wang YL, Rantalainen M, Wilson ID, Tuohy KM, McCartney AL, Gibson GR, Nicholson JK (2009) Topdown systems biology modeling of host metabotype-microbiome associations in obese rodents. J Proteome Res 8:2361-2375. doi: 10.1021/pr8009885

Wall R, Ross RP, Shanahan F, O'Mahony L, O'Mahony C, Coakley M, Hart O, Lawlor P, Quigley EM, Kiely B, Fitzgerald GF,
Stanton C (2009) Metabolic activity of the enteric microbiota influences the fatty acid composition of murine and porcine liver and adipose tissues. Am J Clin Nut 89:1393-1401. doi:10.3945/ ajcn.2008.27023

Willcox DC, Willcox BJ, Todoriki H, Suzuki M (2009) The Okinawan diet: health implications of a low-calorie, nutrientdense, antioxidant-rich dietary pattern low in glycemic load. J Am Coll Nutr 28(Suppl):500S-516S

Williams DE, Knowler WC, Smith CJ, Hanson RL, Roumain J, Saremi A, Kriska AM, Bennett PH, Nelson RG (2001) The effect of Indian or Anglo dietary preference on the incidence of diabetes in Pima Indians. Diabetes Care 24:811-816

Xiong Y, Miyamoto N, Shibata K et al (2004) Short-chain fatty acids stimulate leptin production in adipocytes through the $\mathrm{G}$ proteincoupled receptor GPR41. Proc Natl Acad Sci USA 101:10451050. doi:10.1073/pnas.2637002100

Yang RZ, Lee MJ, Hu H, Pollin TI, Ryan AS, Nicklas BJ, Snitker S, Horenstein RB, Hull K, Goldberg NH, Goldberg AP, Shuldiner AR, Fried SK, Gong DW (2006) Acute-phase serum amyloid A: an inflammatory adipokine and potential link between obesity and its metabolic complications. PLos Med 3:884-894. doi: 10.1371/journal.pmed.0030287

Yin YN, Yu QF, Fu N, Liu XW, Lu FG (2010) Effects of four Bifidobacteria on obesity in high-fat diet induced rats. World $\mathrm{J}$ Gastroenterol 16:3394-3401. doi:10.3748/wjg.v16.i27.3394

Zhang HS, DiBaise JK, Zuccolo A, Kudrna D, Braidotti M, Yu YS, Parameswaran P, Crowell MD, Wing R, Rittmann BE, Krajmalnik-Brown R (2009) Human gut microbiota in obesity and after gastric bypass. Proc Natl Acad Sci USA 106:23652370. doi:10.1073/pnas.0812600106

Zhang CH, Zhang MH, Wang SY, Han RJ, Cao YF, Hua WY, Mao YJ, Zhang XJ, Pang XY, Wei CC, Zhao GP, Chen Y, Zhao LP (2010) Interactions between gut microbiota, host genetics and diet relevant to development of metabolic syndromes in mice. ISME J 4:232-241. doi:10.1038/ismej.2009.112 